Published in final edited form as:

CNS Neurol Disord Drug Targets. 2012 September ; 11(6): 722-738.

\title{
P2Y Receptors in the Mammalian Nervous System: Pharmacology, Ligands and Therapeutic Potential
}

\author{
Gary A. Weisman ${ }^{\star}, 1,2,3$, Lucas T. Woods ${ }^{1,3}$, Laurie Erb ${ }^{1,3}$, and Cheikh I. Seye ${ }^{4}$ \\ ${ }^{1}$ Department of Biochemistry, University of Missouri, Columbia, Missouri, USA \\ ${ }^{2}$ Interdisciplinary Neuroscience Program, University of Missouri, Columbia, Missouri, USA \\ ${ }^{3}$ Christopher S. Bond Life Sciences Center, University of Missouri, Columbia, Missouri, USA \\ ${ }^{4}$ Department of Cellular and Integrative Physiology, Indiana University School of Medicine, \\ Indianapolis, Indiana, USA
}

\section{Abstract}

P2Y receptors for extracellular nucleotides are coupled to activation of a variety of G proteins and stimulate diverse intracellular signaling pathways that regulate functions of cell types that comprise the central nervous system (CNS). There are 8 different subtypes of $\mathrm{P} 2 \mathrm{Y}$ receptor expressed in cells of the CNS that are activated by a select group of nucleotide agonists. Here, the agonist selectivity of these $8 \mathrm{P} 2 \mathrm{Y}$ receptor subtypes is reviewed with an emphasis on synthetic agonists with high potency and resistance to degradation by extracellular nucleotidases that have potential applications as therapeutic agents. In addition, the recent identification of a wide variety of subtype-selective antagonists is discussed, since these compounds are critical for discerning cellular responses mediated by activation of individual P2Y receptor subtypes. The functional expression of $\mathrm{P} 2 \mathrm{Y}$ receptor subtypes in cells that comprise the CNS is also reviewed and the role of each subtype in the regulation of physiological and pathophysiological responses is considered. Other topics include the role of $\mathrm{P} 2 \mathrm{Y}$ receptors in the regulation of blood-brain barrier integrity and potential interactions between different $\mathrm{P} 2 \mathrm{Y}$ receptor subtypes that likely impact tissue responses to extracellular nucleotides in the CNS. Overall, current research suggests that P2Y receptors in the CNS regulate repair mechanisms that are triggered by tissue damage, inflammation and disease and thus $\mathrm{P} 2 \mathrm{Y}$ receptors represent promising targets for the treatment of neurodegenerative diseases.

\section{Keywords}

Neuroinflammation; P2Y receptor; P2Y receptor agonist; P2Y receptor antagonist

\footnotetext{
(C) 2012 Bentham Science Publishers

*Address correspondence to this author at the Department of Biochemistry, 540E Life Sciences Center, 1201 Rollins Road, University of Missouri, Columbia, MO, 65211-7310, USA; Tel: 573-882-5005; Fax: 573-884-2537; weismang @ missouri.edu.

CONFLICT OF INTEREST

The authors confirm that this article content has no conflicts of interest.
} 


\section{INTRODUCTION}

P2 receptors are a diverse group of cell surface nucleotide receptors that can be separated into two structurally distinct subtypes: the P2X receptors that are ligand-gated ion channels and the G protein-coupled P2Y receptors. Genes for seven P2X receptor subtypes (i.e., $\mathrm{P} 2 \mathrm{X} 1-7)$ have been characterized and their physiological function and therapeutic relevance are discussed in other chapters in this issue. $\mathrm{P} 2 \mathrm{Y}$ receptors are seven transmembrane spanning proteins that bind extracellular nucleotides to cause the activation of heterotrimeric $G$ proteins and the transduction of intracellular signaling pathways that regulate a wide variety of cellular responses. To date, eight different subtypes of P2Y receptors have been cloned and characterized in mammalian cells of multiple species and have been shown to be activated by structurally distinct nucleotide agonists, including adenosine 5 '-triphosphate (ATP), adenosine 5' -diphosphate (ADP), uridine 5'-triphosphate (UTP), uridine 5'diphosphate (UDP) and UDP-glucose [1-3], as described in Table 1. Endogenous P2Y receptor (P2YR) agonists are released from cells in the central nervous system (CNS) under various conditions, including exocytosis at nerve terminals [4,5], the opening of pannexin 1 hemi-channels [6-9], oxygen deprivation and apoptosis [4, 6], whereupon they activate all 8 subtypes of $\mathrm{P} 2 \mathrm{Y}$ receptors (i.e., $\mathrm{P}_{2} \mathrm{Y}_{1}, \mathrm{P}_{2} \mathrm{Y}_{2}, \mathrm{P}_{2} \mathrm{Y}_{4}, \mathrm{P}_{2} \mathrm{Y}_{6}, \mathrm{P}_{2} \mathrm{Y}_{11-14}$ ) that are expressed in cells that comprise the CNS (e.g., neurons, astrocytes, microglia and endothelial cells) [3, 10-19]. This review will describe the signaling pathways coupled to activation of each P2YR subtype and the physiological and pathophysiological responses regulated by P2YRs in the CNS. For example, P2YRs have been shown to regulate neurotransmission, cell growth, inflammatory responses and apoptosis [10-13, 20-23]. Recent studies have provided evidence that activation of $\mathrm{P} 2 \mathrm{YRs}$ has both neuroprotective and neurodegenerative consequences in the CNS [24, 25] and, therefore, P2YRs represent novel therapeutic targets for the treatment of neurodegenerative diseases, as will be described for each P2YR subtype. In addition, we will summarize the current state of P2YR subtype-selective agonists and antagonists that could potentially represent promising drugs for modulation of cellular functions in the CNS.

\section{COMMON STRUCTURAL AND SIGNALING FEATURES OF P2Y RECEPTORS}

The primary and secondary structures of P2YRs indicate the presence of an extracellular Nterminus followed by seven transmembrane spanning domains that delineate 3 extracellular loops and 3 intracellular loops and an intracellular C-terminal tail that varies significantly among the P2YR subtypes [3, 26-29]. The number of amino acids in human P2YR subtypes ranges from 328 (for $\mathrm{P}_{2} \mathrm{Y}_{6} \mathrm{R}$ ) to 377 (for $\mathrm{P} 2 \mathrm{Y}_{2} \mathrm{R}$ ) and these subtypes have $\sim 20$ to $50 \%$ homology [30]. Binding of the negatively charged P2YR agonists within the transmembrane domain is likely facilitated by several positively charged amino acids that are conserved among the P2YR subtypes [27, 31, 32] and information from site-directed mutagenesis experiments has suggested a model of the ligand-binding site for some subtypes [33, 34]. Once activated by nucleotide agonists, P2YRs stimulate GDP-GTP exchange by heterotrimeric $\mathrm{G}$ proteins whereupon dissociation of the GTP-Ga subunit modulates the activities of intracellular enzymes, including phospholipase $\mathrm{C}$ and adenylyl cyclase, to 
activate intracellular signaling cascades that regulate multiple cell type-specific responses $[3,35]$. Among the $\mathrm{P} 2 \mathrm{YR}$ subtypes, the $\mathrm{P} 2 \mathrm{Y}_{1}, \mathrm{P}_{2} \mathrm{Y}_{2}, \mathrm{P}_{2} \mathrm{Y}_{4}, \mathrm{P}_{2} \mathrm{Y}_{6}$ and $\mathrm{P} 2 \mathrm{Y}_{11}$ receptors are coupled to $\mathrm{G}_{\mathrm{q}}$ protein and the activation of phospholipase $\mathrm{C}$ which promotes the hydrolysis of the plasma membrane phospholipid phosphatidylinositol 4,5-bisphosphate $\left(\mathrm{PIP}_{2}\right)$ to generate two second messengers, inositol 1,4,5-trisphosphate ( $\left.\mathrm{IP}_{3}\right)$ and diacylglycerol that induce release of $\mathrm{Ca}^{2+}$ from intracellular stores and activate protein kinase $\mathrm{C}$ (PKC), respectively $[3,36]$. Alternatively, $\mathrm{P} 2 \mathrm{Y}_{12}, \mathrm{P}_{2} \mathrm{Y}_{13}$ and $\mathrm{P} 2 \mathrm{Y}_{14}$ receptors are coupled to $\mathrm{G}_{\mathrm{i} / \mathrm{o}}$ proteins which regulate the activity of adenylyl cyclase and production of the downstream effector cyclic adenosine 5'-monophosphate (cAMP) [3, 36]. P2YRs have also been shown to activate additional subfamilies of $\mathrm{G}$ proteins either directly or indirectly through interactions with other plasma membrane receptors, as described below.

P2YRs, like most G protein-coupled receptors, are desensitized by prolonged agonist treatment due to phosphorylation of intracellular sites in the receptor that promotes the binding of $\beta$-arrestins and subsequent receptor internalization and/or degradation [37]. $\beta$ Arrestins can regulate receptor desensitization by interfering with $\mathrm{G}$ protein coupling and interacting with clathrin and AP2 to induce endocytosis [37]. Most P2YRs interact with $\beta$ arrestin-2, although the $\mathrm{P} 2 \mathrm{Y}_{2}$ and $\mathrm{P}_{2} \mathrm{Y}_{4}$ receptors also interact with $\beta$-arrestin 1 [38]. Receptor endocytosis regulated by $\beta$-arrestins has been shown to activate intracellular mitogen-activated protein kinases [37], such as ERK1/2, a target of many P2YR signaling cascades, and differential coupling of P2YRs to $\beta$-arrestins may explain variations in ERK1/2 activation induced by different P2YR agonists [38]. Agonist-induced desensitization of most $\mathrm{P} 2 \mathrm{YRs}$, except for the $\mathrm{P} 2 \mathrm{Y}_{2} \mathrm{R}$, also is dependent on the protein dynamin [38].

\section{P2Y RECEPTOR SUBTYPES}

\section{The $\mathrm{P}_{2} \mathrm{Y}_{1}$ Receptor}

The $\mathrm{P} 2 \mathrm{Y}_{1} \mathrm{R}$ is activated by the endogenous agonist $\mathrm{ADP}\left(\mathrm{EC}_{50}=10 \mathrm{nM}\right)$ and is directly coupled to activation of $G_{q}$ proteins [39]. When the human $P 2 Y_{1} R$ was overexpressed in Sf9 insect cells, then purified and reconstituted in proteoliposomes along with heterotrimeric $\mathrm{G}$ proteins, it was demonstrated that receptor activation was also coupled to activation of $\mathrm{Ga}_{11}$ proteins (determined by increases in 2-methylthio-ADP-induced GTP hydrolysis) whose activity was enhanced by the presence of the GTPase-activating proteins RGS4 and PLC $\beta_{1}$ [40]. The synthetic agonist 2-methylthio-ADP (2-MeS-ADP; $\left.\mathrm{EC}_{50}=2 \mathrm{nM}\right)$ has been widely used to induce $\mathrm{P} 2 \mathrm{Y}_{1} \mathrm{R}$ activation, although it can also activate the $\mathrm{P} 2 \mathrm{Y}_{12}$ and $\mathrm{P} 2 \mathrm{Y}_{13}$ receptors [41]. The 2-MeS-ADP analog (N)-methanocarba-2-methylthio-ADP (MRS2365) was found to be a highly potent and stable agonist at the human $\mathrm{P}_{2} \mathrm{Y}_{1} \mathrm{R}$ with an $\mathrm{EC}_{50}=0.4$ $\mathrm{nM}$ [42]. Other studies have synthesized derivatives of adenosine 5'-O-(1boranotriphosphate) (ATP-a-B) and $\beta, \gamma$-methyl-ATP that are $\mathrm{P}_{2} \mathrm{Y}_{1} \mathrm{R}$ agonists and are relatively insensitive to hydrolysis by nucleoside 5'-triphosphate diphosphohydrolase (NTPDase), as compared to endogenous agonists, suggesting their potential as therapeutic agonists with long-term stability [43, 44]. Similarly, dinucleoside polyphosphate derivatives including diadenosine $\left(\gamma\right.$-borano)pentaphosphate $\left(\mathrm{Ap}_{5}(\gamma-\mathrm{B}) \mathrm{A}\right)$ have proven to be potent and selective $\mathrm{P} 2 \mathrm{Y}_{1} \mathrm{R}$ agonists [45, 46]. Di-(2-MeS)-adenosine 5',5"- $\mathrm{P}^{1}, \mathrm{P}^{4}, \mathrm{a}, \beta$-methylene- 
tetraphosphate and 2-MeS- $\beta, \gamma-\mathrm{CCl}_{2}-\mathrm{ATP}$ also have been shown to be stable $\mathrm{P} 2 \mathrm{Y}_{1} \mathrm{R}$ agonists with potential for the treatment of human disease due to their ability to stimulate insulin secretion in rats and relieve intraocular pressure in rabbits, respectively $[47,48]$.

P2 $Y_{1} R$ activation has been shown to be antagonized by the ATP analogs, ATPaS and $\beta, \gamma-$ methylene-ATP, which act as competitive antagonists, whereas pyridoxal-phosphate-6azophenyl-2',4'-disulphonic acid (PPADS) and suramin were also shown to inhibit P2 $\mathrm{Y}_{1} \mathrm{R}$ activity [49], although these latter compounds are not selective for the $P 2 Y_{1} R$ [50]. Adenosine-3'-phosphate-5'-phosphosulfate (A3P5PS), adenosine-3'-phosphate-5'-phosphate (A3P5P), adenosine-2'-phosphate-5'-phosphate (A2P5P) and adenosine-2',5'-diphosphate are competitive antagonists at the turkey and human $\mathrm{P}_{2} \mathrm{Y}_{1} \mathrm{Rs}$ and A3P5PS and A3P5P were devoid of agonist or antagonist activities at the $\mathrm{P} 2 \mathrm{Y}_{2}, \mathrm{P}_{2} \mathrm{Y}_{4}$ and $\mathrm{P} 2 \mathrm{Y}_{6}$ receptors [51, 52]. These initial observations describing $\mathrm{P} 2 \mathrm{Y}_{1} \mathrm{R}$ antagonism by bisphosphates (i.e., A3P5P) led to the development of synthetic analogs such as N6-methyl 2'-deoxyadenosine 3',5'bisphosphate (N6MABP; or MRS2179) which also antagonizes the $\mathrm{P}_{2} \mathrm{Y}_{1} \mathrm{R}$ without effects on the human $\mathrm{P}_{2} \mathrm{Y}_{2}, \mathrm{P} 2 \mathrm{Y}_{4}$ and $\mathrm{P}_{2} \mathrm{Y}_{6}$ receptors $[53,54]$. Additional synthetic bisphosphate antagonists of the $\mathrm{P}_{2} \mathrm{Y}_{1} \mathrm{R}$ include 2-iodo-N(6)-methyl-(N)-methanocarba-2'deoxyadenosine-3',5'-bisphosphate (MRS2500), which was shown to be a potent and selective $\mathrm{P} 2 \mathrm{Y}_{1} \mathrm{R}$ antagonist [55, 56], and 2-chloro N(6)-methyl-(N)-methanocarba-2'deoxyadenosine-3',5'-bisphosphate (MRS2279), which was shown to be a selective competitive $\mathrm{P} 2 \mathrm{Y}_{1} \mathrm{R}$ antagonist without an effect on $\mathrm{P}_{2} \mathrm{Y}_{2}, \mathrm{P}_{2} \mathrm{Y}_{4}, \mathrm{P}_{2} \mathrm{Y}_{6}, \mathrm{P} 2 \mathrm{Y}_{11}$ and $\mathrm{P} 2 \mathrm{Y}_{12}$ receptors [57]. Other studies have indicated that, whereas N6-methyl modification enhances the antagonist potency of 2'-deoxyadenosine 3',5'-bisphosphate at the $\mathrm{P} 2 \mathrm{Y}_{1} \mathrm{R}$, this effect is inhibited by benzoylation or dimethylation of the N6-amino group of adenosine or by its replacement with methylthio, chloro, or hydroxy groups [58].

The $\mathrm{P} 2 \mathrm{Y}_{1} \mathrm{R}$ is widely expressed in the mammalian brain, including in the cerebral cortex, hippocampus, caudate nucleus, putamen, globus pallidus, habenula, subthalamic nucleus, midbrain and cerebellum [59-61]. The $\mathrm{P}_{2} \mathrm{Y}_{1} \mathrm{R}$ is expressed in Purkinje cells in the cerebellum, in regions of the cerebral cortex, in ischemia-sensitive areas of the hippocampus [61] and in oligodendrocytes and astrocytes in brain and optic nerves [14, 59]. $\mathrm{P} 2 \mathrm{Y}_{1}$ Rs also have been shown to regulate glial cell functions [61]. In hippocampal astrocytes, $\mathrm{P}_{2} \mathrm{Y}_{1} \mathrm{R}$ activation has been suggested to provide neuroprotection from oxidative stress via increased interleukin-6 (IL-6) release [62] and to play roles in brain development and repair [63] and sensory reception $[64,65]$. Other studies indicate that $\mathrm{P} 2 \mathrm{Y}_{1} \mathrm{Rs}$ also are expressed in microglial cells [59, 66], rat neuroprogenitor cells [63], and dorsal root ganglia and horn neurons $[65,67,68]$. Furthermore, recent studies with $\mathrm{P} 2 \mathrm{Y}_{1} \mathrm{R}$ knockout mice indicate that $\mathrm{P} 2 \mathrm{Y}_{1} \mathrm{Rs}$ mediate neurotransmission in the gastrointestinal tract [69].

Consistent with studies indicating the role of the $\mathrm{P}_{2} \mathrm{Y}_{1}$ receptor in increasing cytokine (i.e., IL-6) release [62], intracerebroventricular administration of the $\mathrm{P}_{2} \mathrm{Y}_{1} \mathrm{R}$ antagonist, MRS2179, significantly decreased the expression of IL-6, phospho-RelA (p-RelA), tumor necrosis factor-a, monocyte chemotactic protein-1/chemokine (C-C motif) ligand 2 (CCL2), and interferon-inducible protein-10/chemokine (C-X-C motif) ligand 10 (CXCL10) mRNA in a rat model of cerebral ischemia/reperfusion [25]. While previous studies indicated that P2 $Y_{1}$ R-induced IL-6 release provided neuroprotection [62], intracerebroventricular 
administration of the $\mathrm{P} 2 \mathrm{Y}_{1} \mathrm{R}$ agonist MRS2365 was shown to increase cerebral infarct volume due to cerebral ischemia/reperfusion, whereas administration of the $\mathrm{P} 2 \mathrm{Y}_{1} \mathrm{R}$ antagonist MRS2179 decreased infarct volume [25]. Additionally, P2 $\mathrm{Y}_{1} \mathrm{R}$ and p-RelA colocalized with glial fibrillary acidic protein-positive astrocytes, suggesting that $\mathrm{P} 2 \mathrm{Y}_{1} \mathrm{R}$ expression in cortical astrocytes mediates cytokine/chemokine-induced damage that occurs during cerebral ischemia/reperfusion, which can be prevented by antagonists of the P2Y $Y_{1}$ [25]. The effects of $\mathrm{P} 2 \mathrm{Y}_{1} \mathrm{R}$ agonism/antagonism appear to be experimental model-dependent making it difficult to determine the potential therapeutic role in treatment of ischemiarelated damage. In brain sections from Alzheimer's disease (AD) patients, $\mathrm{P} 2 \mathrm{Y}_{1} \mathrm{Rs}$ in neurons have been shown to colocalize with neurofibrillary tangles and neuritic plaques, as compared to samples from control patients [70]. While the significance of these observations is unclear, $\mathrm{P} 2 \mathrm{Y}_{1} \mathrm{R}$-mediated stimulation of $\mathrm{G}_{\mathrm{q}}$ protein has been shown to activate the small GTPase cytoskeletal modulator Rac [71], which recent studies have shown enhances axonal elongation [72], although this effect was shown to occur through a mechanism involving adenylate cyclase 5 and the phosphatidylinositol 3-kinase (PI3K)/Akt pathway. Nonetheless, these data suggest that the $\mathrm{P} 2 \mathrm{Y}_{1} \mathrm{R}$ may play a neuroprotective role in $\mathrm{AD}$ by promoting axonal elongation to counteract the neurotoxic effects of neurofibrillary tangles. While further research is needed to validate this speculative therapeutic pathway, it stands to reason that selective $\mathrm{P} 2 \mathrm{Y}_{1} \mathrm{R}$ agonists and antagonists should be investigated for therapeutic utility in the modulation of neurodegenerative disease phenotypes, such as AD, amyotrophic lateral sclerosis (ALS) and Parkinson's disease.

$\mathrm{P} 2 \mathrm{Y}_{1} \mathrm{R}$ activation also has been shown to cause PKC-dependent phosphorylation of the capsaicin receptor (a VR1 cation channel) that can alter the perception of pain [73]. The potential therapeutic use of $\mathrm{P} 2 \mathrm{Y}_{1} \mathrm{R}$ antagonists in pain perception is highlighted by a recent study showing significantly decreased tactile allodynia in a rat model of bone pain following treatment with the $\mathrm{P} 2 \mathrm{Y}_{1} \mathrm{R}$ antagonist MRS2179 [74]. Additionally, intracerebroventricular injection of the $\mathrm{P} 2 \mathrm{Y}_{1} \mathrm{R}$ agonist $\mathrm{ADP} \beta \mathrm{S}$ was shown to increase anxiolytic-like behavior in a rat model of anxiety [75]. Furthermore, this behavior was attenuated by injection of the $\mathrm{P} 2 \mathrm{Y}_{1} \mathrm{R}$ antagonist MRS2179, suggesting another possible therapeutic pathway that may be exploited using specific $\mathrm{P} 2 \mathrm{Y}_{1} \mathrm{R}$ antagonists.

\section{The $\mathrm{P}_{2} \mathrm{Y}_{2}$ Receptor}

The $\mathrm{P} 2 \mathrm{Y}_{2} \mathrm{R}$ is activated equipotently by the fully ionized forms of ATP or UTP (i.e., by $\mathrm{NTP}^{4-}$ ) with an $\mathrm{EC}_{50} \sim 0.5-3 \mu \mathrm{M}$ [76-79], suggesting that this P2YR subtype is primarily activated in close proximity to released nucleotides or under conditions associated with high levels of extracellular ATP and UTP (e.g., inflammation and apoptosis). It seems likely that the negatively-charged triphosphate moieties of these structurally distinct purine (i.e., ATP) and pyrimidine (i.e., UTP) nucleotides promote agonist binding to the $\mathrm{P} 2 \mathrm{Y}_{2} \mathrm{R}$, since selective deletion of positively charged amino acids in the $6^{\text {th }}$ and $7^{\text {th }}$ transmembrane domains inhibits $\mathrm{P} 2 \mathrm{Y}_{2} \mathrm{R}$ activity [27]. Uridine-5'-O-(3-thio)triphosphate (UTPyS) has been shown to be equally potent to UTP as a $\mathrm{P} 2 \mathrm{Y}_{2} \mathrm{R}$ agonist and relatively resistant to hydrolysis by alkaline or acid phosphatase and apyrase [78]. Diadenosine tetraphosphate $\left(\mathrm{Ap}_{4} \mathrm{~A}\right)$ displays relatively potent $\left(\mathrm{EC}_{50}=720 \mathrm{nM}\right)$ agonist activity at the $\mathrm{P}_{2} \mathrm{Y}_{2} \mathrm{R}$ and has been suggested to be an endogenous agonist [80]. The observation that dinucleoside 
polyphosphates have agonist activity at $\mathrm{P} 2 \mathrm{Y}$ receptors led to pharmacological investigations of similar compounds, such as $\mathrm{P}^{1}, \mathrm{P}^{4}$-di(uridine-5'-) tetraphosphate $\left(\mathrm{Up}_{4} \mathrm{U}\right.$; INS365; Diquafosol), which was shown to be a potent agonist of the $\mathrm{P}_{2} \mathrm{Y}_{2} \mathrm{R}\left(\mathrm{EC}_{50}=100 \mathrm{nM}\right)$ and also displayed agonist activity at the $\mathrm{P}_{2} \mathrm{Y}_{4} \mathrm{R}$ and the $\mathrm{P}_{2} \mathrm{Y}_{6} \mathrm{R}$ [81]. Similarly, $\mathrm{P} 1$-(inosine 5'-) $\mathrm{P}^{4}$-(uridine 5'-) tetraphosphate ( $\mathrm{Ip}_{4} \mathrm{U}$; INS45973), which has $\mathrm{EC}_{50}$ values for the $\mathrm{P}_{2} \mathrm{Y}_{2} \mathrm{R}$ and the $\mathrm{P}_{2} \mathrm{Y}_{4} \mathrm{R}$ of $\sim 280 \mathrm{nM}$ and an $\mathrm{EC}_{50}$ for the $\mathrm{P}_{2} \mathrm{Y}_{6} \mathrm{R}$ of $>10 \mu \mathrm{M}$, has been used intravenously in mice to demonstrate that activation of the $\mathrm{P} 2 \mathrm{Y}_{2} \mathrm{R}$ decreases blood pressure and increases renal $\mathrm{Na}^{+}$excretion [82]. The relative potency and selectivity of these compounds along with the development of the more hydrolytically stable $\mathrm{P} 2 \mathrm{Y}_{2} \mathrm{R}$ agonist $\mathrm{P}(1)$-(uridine 5')-P(4)-(2'-deoxycytidine 5')-tetraphosphate ( $\mathrm{dCp}_{4} \mathrm{U}$; INS37217; Denusofol) $[83,84]$ led to several clinical investigations into the therapeutic potential of these $\mathrm{P}_{2} \mathrm{Y}_{2} \mathrm{R}$ agonists to increase fluid flow across epithelial cell membranes that has been shown to be regulated by the $\mathrm{P}_{2} \mathrm{Y}_{2} \mathrm{R}$ [85-88]. However, recent Phase III clinical trials for INS37217 in the treatment of cystic fibrosis and INS365 in the treatment of dry eye, two epithelial-based diseases with underlying defects in fluid flow, failed to achieve their primary endpoints. Other documented P2 $\mathrm{Y}_{2} \mathrm{R}$ agonists include 2'-amino-2'-deoxy-UTP, 6-nitro-UTP, UTPaS and 2'-deoxy-UTPaS [89], 2-thio-UTP [90], uridine-5'-tetraphosphate 8-phenyl ester (MRS2768), dihalomethylene phosphonate analogues and the 2-thio analogue of INS37217 [91]. A recently developed $\mathrm{P}_{2} \mathrm{Y}_{2} \mathrm{R}$ agonist, 4-thiouridine-5'-O-( $\beta, \gamma$-difluoromethylene) triphosphate (PSB1114), shows 60-fold increased selectivity at the $\mathrm{P} 2 \mathrm{Y}_{2} \mathrm{R}$, as compared to the $\mathrm{P} 2 \mathrm{Y}_{4} \mathrm{R}$ or the $\mathrm{P} 2 \mathrm{Y}_{6} \mathrm{R}$ [92], which potentially provides an agent for selective in vivo activation of the $\mathrm{P} 2 \mathrm{Y}_{2} \mathrm{R}$ among the known uridine nucleotide receptor subtypes.

P2 $\mathrm{Y}_{2} \mathrm{R}$ activation mediates $\mathrm{G}_{\mathrm{q}}$-dependent stimulation of phospholipase $\mathrm{C}$ (PLC), although the $P 2 Y_{2} R$ has been shown to induce GTPy $\left[{ }^{35} S\right]$ incorporation into $G_{q}, G_{o}$ and $G_{12}$ proteins [93-94]. Only $G_{q}$ appears to be directly coupled to $P 2 Y_{2} R$ activation, since activation of $G_{o}$ and $\mathrm{G}_{12}$ proteins was shown to require the presence of the consensus integrin-binding arginine-glycine-aspartic acid (RGD) motif in the first extracellular loop of the $\mathrm{P}_{2} \mathrm{Y}_{2} \mathrm{R}$ whose deletion prevents receptor interaction with $a_{v}$ integrins and the activation $G_{0}$ and $G_{12}$, but not $\mathrm{G}_{\mathrm{q}}$ proteins [93-95]. Although activation of PLC by the $P 2 \mathrm{Y}_{2} \mathrm{R}$ has been shown to require GTP binding to $\mathrm{Ga}_{\mathrm{q} 11}$ [96], the $\mathrm{P} 2 \mathrm{Y}_{2} \mathrm{R}$ also has been found to modulate phospholipase $\mathrm{C}$ activities via $\mathrm{Ga}_{\mathrm{q} 16}$ [97] and $\mathrm{G} \beta \gamma_{\mathrm{i} 3}$ [96].

There have been few $\mathrm{P} 2 \mathrm{Y}_{2} \mathrm{R}$-selective antagonists described, although PPADS and suramin are non-selective $\mathrm{P}_{2} \mathrm{Y}_{2} \mathrm{R}$ antagonists [98, 99]. The non-nucleotide compound 1-amino-4-(2methoxyphenyl)-2-sulfoanthraquinone (PSB716) has been shown to be a potent $\mathrm{P} 2 \mathrm{Y}_{2} \mathrm{R}$ antagonist with an $\mathrm{IC}_{50}$ value in the low micromolar range [100]. To date, the most reliable means of inhibiting $\mathrm{P}_{2} \mathrm{Y}_{2} \mathrm{R}$ function has been the use of $P 2 \mathrm{Y}_{2} R$-selective antisense oligonucleo-tides or siRNA or deletion of the $P 2 Y_{2} R$ in transgenic mice $[24,101,102]$. Accordingly, there is a critical need for the development of $\mathrm{P} 2 \mathrm{Y}_{2} \mathrm{R}$-selective antagonists and agonists, particularly those that can cross the blood-brain barrier, since this P2YR subtype represents a promising target in the treatment of neuroinflammatory and neurodegenerative diseases, such as Alzheimer's disease, as described below.

The $\mathrm{P} 2 \mathrm{Y}_{2} \mathrm{R}$ subtype likely plays a role in CNS functions predominantly under pathophysiological conditions, including inflammation and bacterial infection [103-106]. 
The $\mathrm{P} 2 \mathrm{Y}_{2} \mathrm{R}$ has been found to be upregulated in cell and animal models under a variety of conditions associated with inflammation or injury [16, 107-111], including spinal cord injury [112] and brain trauma [113], which suggests the possibility that the $P 2 Y_{2} R$ plays a protective role in the CNS. $\mathrm{P}_{2} \mathrm{Y}_{2} \mathrm{R}$ expression is upregulated by treatment of rat primary cortical neurons with the proinflammatory cytokine interleukin-1 $\beta$ (IL-1 $\beta$ ) [16], and levels of IL- $1 \beta$ have been shown to be elevated in the brains of $\mathrm{AD}$ patients, as compared to normal controls $[114,115]$. Consistent with a role in inflammation, $\mathrm{P} 2 \mathrm{Y}_{2} \mathrm{R}$ expression under proinflammatory conditions has been shown to require binding to the $P 2 Y_{2} R$ promoter of $\mathrm{NF}-\kappa \mathrm{B}$ [116], a transcription factor known to regulate gene expression in inflammation [117].

$\mathrm{P} 2 \mathrm{Y}_{2} \mathrm{R}$ activation has been shown to increase the migration and proliferation of astrocytic and microglial cells $[24,93,118-120]$. The mechanism of $\mathrm{P}_{2} \mathrm{Y}_{2} \mathrm{R}$-mediated cell migration appears to require more than $\mathrm{G}_{\mathrm{q}}$-coupled activation of PLC, since cytoskeletal rearrangements and cell migration induced by the $\mathrm{P} 2 \mathrm{Y}_{2} \mathrm{R}$ agonist UTP were abolished in astrocytoma cells that express a mutant $\mathrm{P} 2 \mathrm{Y}_{2} \mathrm{R}$ in which aspartic acid in a consensus integrin-binding RGD motif was modified to glutamic acid to generate RGE, which prevents the $\mathrm{P} 2 \mathrm{Y}_{2} \mathrm{R}$ from binding to $\mathrm{a}_{\mathrm{v}}$ integrins [93-94]. This result suggests a requirement for $\mathrm{P} 2 \mathrm{Y}_{2} \mathrm{R}$ interaction with $\mathrm{a}_{\mathrm{v}}$ integrins to mediate UTP-induced cell migration. Consistent with this conclusion, UTP-induced $\mathrm{G}_{0}$-dependent Rac1 and $\mathrm{G}_{12}$-dependent RhoA activation, pathways well known to regulate actin polymerization and depolymerization required for cell migration [121, 122], were absent in cells expressing the RGE-mutant of the $\mathrm{P} 2 \mathrm{Y}_{2} \mathrm{R}$ [93-95]. Other data suggest that increases in cell proliferation caused by $\mathrm{P} 2 \mathrm{Y}_{2} \mathrm{R}$ activation are due to the ability of the $\mathrm{P} 2 \mathrm{Y}_{2} \mathrm{R}$ to induce phosphorylation and activation of growth factor receptors that leads to increases in the activities of the mitogen-activated protein kinases ERK1/2 and the related adhesion focal tyrosine kinase (RAFTK; Pyk 2) via a pathway dependent upon Src and Shc/Grb2 [123-125]. The P2 $\mathrm{Y}_{2} \mathrm{R}$ contains Src-homology-3 (SH3) binding motifs in the intracellular C-terminal domain that when deleted can prevent growth factor receptor activation $[125,126]$, suggesting that agonist-induced Src binding to these SH3-binding sites can regulate $\mathrm{P}_{2} \mathrm{Y}_{2} \mathrm{R}$-mediated cell proliferation. Other studies indicate that the $\mathrm{C}$-terminal domain of the $\mathrm{P}_{2} \mathrm{Y}_{2} \mathrm{R}$ can interact with the actin-binding protein filamin A, a regulator of cytoskeletal rearrangements [101], and the C-terminal domain also has been shown to play a role in $\mathrm{P}_{2} \mathrm{Y}_{2} \mathrm{R}$ desensitization and internalization [127]. The $\mathrm{P} 2 \mathrm{Y}_{2} \mathrm{R}$ also can regulate cell migration by activation of growth factor receptors [128], suggesting that a wide variety of cellular functions are likely mediated by $\mathrm{P} 2 \mathrm{Y}_{2} \mathrm{R}$ interactions with integrins, growth factor receptors and cytoskeletal proteins well beyond the ability of the $\mathrm{P} 2 \mathrm{Y}_{2} \mathrm{R}$ to mediate the $\mathrm{G}_{\mathrm{q}}$-dependent activation of PLC.

Current data indicate that $\mathrm{P} 2 \mathrm{Y}_{2} \mathrm{R}$ expression is relatively low in neurons, but can be upregulated by the proinflammatory cytokine IL-1 $\beta$ [16]. Increased $\mathrm{P} 2 \mathrm{Y}_{2} \mathrm{R}$ expression in neurons is likely to have neuroprotective effects, since $\mathrm{P} 2 \mathrm{Y}_{2} \mathrm{R}$ activation promotes neurite outgrowth [129] and the a-secretase-dependent degradation of amyloid precursor protein (APP) to generate the non-amyloidogenic soluble APPa peptide, rather than the neurotoxic $A \beta_{1-42}$ peptide associated with the pathophysiology of Alzheimer's disease $[16,130]$. In mouse primary microglial cells, the $\mathrm{P} 2 \mathrm{Y}_{2} \mathrm{R}$ is upregulated by $\mathrm{A} \beta_{1-42}$, whereupon $\mathrm{P} 2 \mathrm{Y}_{2} \mathrm{R}$ 
activation increases the phagocytosis and degradation of neurotoxic forms of $\mathrm{A} \beta[24,105$, 131]. Interestingly, studies have shown that $\mathrm{P} 2 \mathrm{Y}_{2} \mathrm{R}$ expression is decreased in the parietal cortex of $\mathrm{AD}$ patients and this loss of $\mathrm{P}_{2} \mathrm{Y}_{2} \mathrm{R}$ expression was correlated with neuropathology and synapse loss [132]. These observations suggest that the loss of neuroprotective functions provided by the $\mathrm{P} 2 \mathrm{Y}_{2} \mathrm{R}$ may contribute to disease pathogenesis in $\mathrm{AD}$. Other potentially neuroprotective effects mediated by the $\mathrm{P} 2 \mathrm{Y}_{2} \mathrm{R}$ include the regulation of synaptic transmission through the induction of intracellular calcium waves in astrocytic cells [133] and the upregulation of anti-apoptotic protein expression which promotes cell survival [134]. Activation of $\mathrm{P} 2 \mathrm{Y}_{2} \mathrm{Rs}$ also has been shown to resensitize ionotropic $\mathrm{P} 2 \mathrm{X}_{2}$ receptors in bladder sensory neurons [135] and vanilloid type 1 channels (TRPV1) in kidney sensory neurons [136]. The ability of the $\mathrm{P}_{2} \mathrm{Y}_{2} \mathrm{R}$ to activate metalloproteases, including TNF- $\mathrm{a}$ converting enzyme (TACE; or ADAM17) [16], may contribute to the AD phenotype through the production of $\mathrm{TNFa}$, which has been shown to be upregulated in the brain and cerebrospinal fluid of AD patients [137, 138]. Taken together, the $\mathrm{P}_{2} \mathrm{Y}_{2} \mathrm{R}$ represents a promising target to promote neuroprotection in neurodegenerative diseases through the combined activation of $\mathrm{P}_{2} \mathrm{Y}_{2} \mathrm{Rs}$ in astrocytes, microglial cells and neurons.

The development of neurodegenerative diseases has been shown to be preceded by malfunctions in the cerebrovascular system, including decreased blood flow in the brain and breakdown of the blood-brain barrier (BBB) [139-141]. It is known that microvascular cells (i.e., endothelium and pericytes) affect neuronal functions by altering blood flow, BBB function and glucose/nutrient supply [140, 141]. These cells are also responsible for the clearance of toxic molecules and the secretion of trophic factors and extracellular matrix molecules required for proper neuronal functioning [140, 142]. It is, therefore, important to consider cerebrovascular function in relation to brain health.

Studies in various vasculature systems, including the cerebral microvasculature, have shown that intravenous or intraluminal application of ATP and/or UTP induces endotheliumdependent relaxation of blood vessels and a decrease in blood pressure, which has been attributed to activation of the endothelial $\mathrm{P} 2 \mathrm{Y}_{2} \mathrm{R}$ [82, 143-148]. Fewer in vivo studies have explored the effects of nucleotides on vascular permeability properties, although studies in frogs have shown that ATP increases the ion permeability of cerebral venules [149] and mesenteric microvascular permeability as measured by changes in hydraulic conductivity [150]. $\mathrm{P} 2 \mathrm{Y}_{2} \mathrm{Rs}$, which are expressed along with $\mathrm{P}_{2} \mathrm{Y}_{1,4,6}$ receptors in mouse aortic endothelium [151], increase blood flow through the release of NO [145]. In human mammary arteries, several $\mathrm{P} 2 \mathrm{Y}$ receptor subtypes, including $\mathrm{P} 2 \mathrm{Y}_{1,2,4,6}$ receptors, are thought to mediate vasodilatation by releasing NO, prostanoids or endothelium-derived hyperpolarizing factor [152]. In contrast, vascular smooth muscle cells express many P2X and $\mathrm{P} 2 \mathrm{Y}$ receptors [153] that cause blood vessel constriction, which together help regulate vascular tone.

Cerebral microvessels are closely associated with several types of brain cells, including microglia and neuronal processes, and are encircled by the end feet of astrocytes, which are also thought to play a role in the regulation of local blood flow and barrier function [154]. Immunohistochemistry studies in rat brain slices indicate that the $\mathrm{P} 2 \mathrm{Y}_{2} \mathrm{R}$ and the $\mathrm{P} 2 \mathrm{Y}_{4} \mathrm{R}$ are strongly expressed in astrocytic end feet at the gliovascular interface and application of ATP 
to freshly prepared brain slices triggers calcium waves in the astrocytic end feet that are propagated along the vessel wall, which the authors speculate is important for regulation of vascular permeability and tone [155]. Furthermore, Lewis et al., demonstrated in rat cerebral tissue that exogenous or extraluminal application of ATP evokes transient vasoconstriction of arterioles followed by sustained vasodilation, whereas UTP and UDP evoke sustained vasoconstriction [156]. Thus, the type of nucleotide and the route of administration (intravenous $v s$ extraluminal) cause profound differences in vascular responses that are important to consider for drug development.

\section{The $\mathrm{P}_{2} \mathrm{Y}_{4}$ Receptor}

The human $\mathrm{P}_{2} \mathrm{Y}_{4} \mathrm{R}$ is activated by $\mathrm{UTP}\left(\mathrm{EC}_{50}=73 \mathrm{nM}\right)$, but not by ATP, whereas the rat and mouse $\mathrm{P}_{2} \mathrm{Y}_{4}$ Rs are activated equipotently by ATP and UTP, similar to the P2 ${ }_{2} \mathrm{R}[26$, 89, 157-159]. Molecular docking studies indicate that the agonist binding site for the $\mathrm{P}_{2} \mathrm{Y}_{4} \mathrm{R}$ is similar to the $\mathrm{P} 2 \mathrm{Y}_{2} \mathrm{R}$ with some variation in the second transmembrane domain and the second extracellular loop [89]. Activation of the $\mathrm{P} 2 \mathrm{Y}_{4} \mathrm{R}$ has been shown to couple to $\mathrm{G}_{\mathrm{q}^{-}}$ and $\mathrm{G}_{\mathrm{O}}$-dependent stimulation of PLC $\beta[26,160]$ and the activation of Rho [161]. ATP has been shown to act as an antagonist at the human $\mathrm{P} 2 \mathrm{Y}_{4} \mathrm{R}[160]$ and amino acid variations in the second extracellular loop and the N-terminal domain were found to play a role in determining whether ATP functions as an agonist or antagonist at mammalian $\mathrm{P}_{2} \mathrm{Y}_{4} \mathrm{Rs}$ [162]. In addition to UTP and ATP, $\mathrm{P} 2 \mathrm{Y}_{4} \mathrm{R}$ agonists include UTP $\gamma \mathrm{S}$ [163], 5-bromo-UTP [26], INS365, INS37217, and INS45973 [81-83]. However, all five of these compounds also display agonist activity at other $\mathrm{P} 2 \mathrm{Y}$ receptors, especially the $\mathrm{P} 2 \mathrm{Y}_{2} \mathrm{R}$. To date, selective $\mathrm{P} 2 \mathrm{Y}_{4} \mathrm{R}$ agonists have not been generated, although the compound 2'-azido-2'-deoxy-UTP has been shown to display slight selectivity for the $\mathrm{P} 2 \mathrm{Y}_{4} \mathrm{R}$ over the $\mathrm{P} 2 \mathrm{Y}_{2} \mathrm{R}$ (human $\mathrm{P} 2 \mathrm{Y}_{4} \mathrm{R}$ : $\mathrm{EC}_{50}=1 \mu \mathrm{M}$; human $\mathrm{P} 2 \mathrm{Y}_{2} \mathrm{R}: \mathrm{EC}_{50}=5 \mu \mathrm{M}$ ) [89]. Similarly, definitive selective $\mathrm{P}_{2} \mathrm{Y}_{4} \mathrm{R}$ antagonists have not been generated, although the non-specific $\mathrm{P} 2 \mathrm{Y}$ receptor inhibitor PPADS was shown to potently inhibit the UTP response at the human P2 $\mathrm{Y}_{4} \mathrm{R}$ [160].

While little is known about the physiological or pathological effects of $\mathrm{P} 2 \mathrm{Y}_{4} \mathrm{R}$ activation in the CNS, P2Y $\mathrm{Y}_{4} \mathrm{R}$ mRNA has been shown to be expressed in human brain [164] and in rat hippocampal pyramidal neurons where it has been suggested to have a presynaptic inhibitory role on the release of glutamate [21]. $\mathrm{P} 2 \mathrm{Y}_{4} \mathrm{R}$ expression in astrocytes and microglial cells also has been extensively documented [14, 66, 157, 165], however, the physiological role of the receptor is unclear and may be complementary to the $\mathrm{P} 2 \mathrm{Y}_{2} \mathrm{R}$. $\mathrm{P}_{2} \mathrm{Y}_{4} \mathrm{Rs}$ are expressed in glial end feet in proximity to blood vessel walls, similar to $\mathrm{P} 2 \mathrm{Y}_{2} \mathrm{Rs}$ [155], where their activation has been suggested to regulate BBB function, blood flow, metabolic trafficking and water homeostasis $[155,166]$. The $\mathrm{P}_{2} \mathrm{Y}_{4} \mathrm{R}$ also has been shown to inhibit $\mathrm{K}^{+}$currents in myocytes of rat cerebral arteries in a Rho-dependent manner [161].

\section{The $\mathrm{P}^{2} \mathrm{Y}_{6}$ Receptor}

The $\mathrm{P} 2 \mathrm{Y}_{6} \mathrm{R}$ is activated preferentially by $\mathrm{UDP}\left(\mathrm{EC}_{50}=15 \mathrm{nM}\right)$ and to a lesser extent by UTP [167]. UDP $\beta S$ has been shown to be a more stable $\mathrm{P}_{2} \mathrm{Y}_{6} \mathrm{R}$ agonist, although this compound also displays agonist activity at the $\mathrm{P}_{2} \mathrm{Y}_{14} \mathrm{R}$ [163]. The synthetic compound 5iodo-UDP (MRS2693) has been shown to be a selective agonist for the human P2 ${ }_{6} R$ [168]. Interestingly, intraperitoneal injection of MRS2693 was shown to have a protective effect on 
skeletal muscle in a mouse model of ischemia [169]. The compound 3-phenacyl-UDP (PSB0474) is a relatively selective agonist of the $\mathrm{P}_{2} \mathrm{Y}_{6} \mathrm{R}$, as compared to the $\mathrm{P} 2 \mathrm{Y}_{2} \mathrm{R}$ and the $\mathrm{P}_{2} \mathrm{Y}_{4} \mathrm{R}$ [90]. The diuridine triphosphate analog INS48823 also has been shown to be a potent and selective $\mathrm{P}_{2} \mathrm{Y}_{6} \mathrm{R}$ agonist $\left(\mathrm{EC}_{50}=200 \mathrm{nM}\right)$ [81] that, similar to INS365 and INS37217, can increase fluid flow across epithelial cell membranes [170]. Additionally, INS48823 has been shown to activate the NF- $\kappa B$ pathway in osteoclasts to increase cell survival [171]. Other $\mathrm{P}_{2} \mathrm{Y}_{6} \mathrm{R}$ agonists include $\alpha, \beta$-methylene-UDP [91] and 5-bromo-UTP [167]. The $P 2 Y_{6} R$ activates $P L C \beta$ in a $G_{q}$-dependent manner [172], but has been shown to regulate pertussis toxin (PTX)-sensitive, voltage-gated $\mathrm{Ca}^{2+}$ currents in rat sympathetic neurons, suggesting the involvement of $\mathrm{G}_{\mathrm{i} / \mathrm{o}}$ [173]. The $\mathrm{P} 2 \mathrm{Y}_{6} \mathrm{R}$ also can mediate $\mathrm{G}_{12 / 13^{-}}$ dependent Rho activation, similar to the $\mathrm{P} 2 \mathrm{Y}_{2} \mathrm{R}$, although the involvement of integrins in this pathway has not been determined [174].

Diisothiocyanate derivatives of 1,2-diphenylethane (MRS2567) and 1,4-di(phenylthioureido)butane (MRS2578) have been demonstrated to be potent and selective antagonists at the rat and human $\mathrm{P} 2 \mathrm{Y}_{6} \mathrm{R}\left(\mathrm{IC}_{50}\right.$ values $\sim 40-130 \mathrm{nM}$ ), with no effect on responses induced by agonists of $\mathrm{P}_{2} \mathrm{Y}_{1}, \mathrm{P}_{2} \mathrm{Y}_{2}, \mathrm{P}_{2} \mathrm{Y}_{4}$ and $\mathrm{P} 2 \mathrm{Y}_{11}$ receptors [175]. A derivative of 1,4-phenylendiisothiocyanate (MRS2575) also displays $\mathrm{P}_{2} \mathrm{Y}_{6} \mathrm{R}$ antagonist activity, but only at the human $\mathrm{P}_{2} \mathrm{Y}_{6} \mathrm{R}$ [175]. Among the non-selective P2YR antagonists, reactive blue 2 was shown to be more potent than PPADS and suramin at the $P 2 Y_{6} R$ [176].

$\mathrm{P}_{2} \mathrm{Y}_{6} \mathrm{R}$ mRNA is expressed throughout the human brain, but at highest levels in amygdala, cingulate gyrus, nucleus accumbens and putamen [164]. P2 $\mathrm{Y}_{6} \mathrm{R}$ mRNA also has been identified in mouse superior cervical ganglion [177], rat dorsal-root ganglion neurons [65, 67] and rat pyramidal hippocampal neurons [21]. Astrocytes in the cerebellum and cortex of rats also have $\mathrm{P} 2 \mathrm{Y}_{6} \mathrm{R}$ activity $[14,178]$. Similar to the $\mathrm{P} 2 \mathrm{Y}_{2} \mathrm{R}, \mathrm{P} 2 \mathrm{Y}_{6} \mathrm{R}$ activation has been shown to increase the phagocytotic activity of microglia [179, 180], a response that was inhibited by the $\mathrm{P}_{2} \mathrm{Y}_{6} \mathrm{R}$ antagonist MRS2578. These observations suggest that a range of endogenous nucleotides and synthetic agonists/antagonists that act at different P2YR subtypes can be exploited therapeutically to induce neuroprotective responses, such as the microglia-dependent phagocytosis of neurotoxic forms of $A \beta[24,131]$. Injury can enhance $\mathrm{P}_{2} \mathrm{Y}_{6} \mathrm{R}$ expression in rat astroglial cells [113] and $\mathrm{P}_{2} \mathrm{Y}_{6} \mathrm{Rs}$ in microglial cells are activated in response to bacterial lipopolysaccharide, implicating a role in neuroinflammation [66]. Thus, these data suggest that the $\mathrm{P}_{2} \mathrm{Y}_{6} \mathrm{R}$, along with the other uridine nucleotide receptors, (i.e., $\mathrm{P} 2 \mathrm{Y}_{2} \mathrm{R}$ and $\mathrm{P} 2 \mathrm{Y}_{4} \mathrm{R}$ ) can regulate protective mechanisms in the CNS under a variety of pathophysiological conditions. Other studies indicate that $\mathrm{P}_{2} \mathrm{Y}_{4}$ and $\mathrm{P} 2 \mathrm{Y}_{6}$ receptors form homo- and hetero-oligomeric complexes in neuronal cells and dimeric $\mathrm{P}_{2} \mathrm{Y}_{4} \mathrm{Rs}$ and monomeric $\mathrm{P}_{2} \mathrm{Y}_{6} \mathrm{Rs}$ can partition into lipid rafts in synaptosomes [181], suggesting the possibility of complex P2YR interactions in the CNS.

\section{The P2Y $_{11}$ Receptor}

The human P2 $\mathrm{Y}_{11} \mathrm{R}$ is activated by ATP and leads to the activation of both PLC (EC $\mathrm{E}_{50}$ for $\mathrm{IP}_{3}$ production $\left.=65 \mu \mathrm{M}\right)$ and adenylyl cyclase $\left(\mathrm{EC}_{50}\right.$ for $\mathrm{cAMP}$ production $\left.=17 \mu \mathrm{M}\right)$, although ATPyS and 3'-O-(4-benzoyl)benzoyl adenosine 5'-triphosphate (BzATP) are more potent agonists than ATP [182]. UTP, in addition to ATP, has been shown to activate the 
$\mathrm{P} 2 \mathrm{Y}_{11} \mathrm{R}$ expressed in astrocytoma cells [183]. Interestingly, the ATP analogue 2-propylthio$\beta, \gamma$-dichloromethylene-D-ATP (AR-C67085), which had previously been shown to inhibit platelet aggregation through $\mathrm{P} 2 \mathrm{Y}_{12} \mathrm{R}$ antagonism [184], was shown to be a potent $\mathrm{P} 2 \mathrm{Y}_{11} \mathrm{R}$ agonist $\left(\mathrm{EC}_{50}\right.$ for $\mathrm{IP}_{3}$ production $=9 \mu \mathrm{M} ; \mathrm{EC}_{50}$ for $\mathrm{cAMP}$ production $\left.=1.5 \mu \mathrm{M}\right)$ [182]. The non-nucleotide phosphoric acid derivative 4,4'-(carbonylbis(imino-3,1-phenylenecarbonylimino-3,1-(4-methyl-phenylene)carbony-limino))-bis1,3-xylene-a,a'-diphosphonic acid (NF546) is a selective $\mathrm{P}_{2} \mathrm{Y}_{11} \mathrm{R}$ agonist that has been shown to stimulate IL-8 release from human dendritic cells with similar potency as ATP $\gamma \mathrm{S}$ [185]. Nicotinic adenine dinucleotide (NAD+) and nicotinic adenine dinucleotide phosphate (NADP+) have been shown to be agonists of $\mathrm{P} 2 \mathrm{Y}_{11}$ Rs expressed in human granulocytes and astrocytoma cells, respectively $[186,187]$. The $\mathrm{P}_{2} \mathrm{Y}_{11} \mathrm{R}$ can regulate both $\mathrm{G}_{\mathrm{s}}$-dependent activation of adenylyl cyclase and $\mathrm{G}_{\mathrm{q}}$-dependent activation of PLC [183, 188-190]. P2Y ${ }_{11}$ Rs expressed in astrocytoma cells mediate UTP-induced PLC activation by a pertussis toxin (PTX)-sensitive mechanism and ATP-induced PLC activation by a PTX-insensitive mechanism, indicating coupling to PLC via both $\mathrm{G}_{\mathrm{o}}$ and $\mathrm{G}_{\mathrm{q}}$ proteins [183]. The coupling of the $\mathrm{P} 2 \mathrm{Y}_{11} \mathrm{R}$ to multiple $\mathrm{G}$ proteins may be due to the ability of the $\mathrm{P} 2 \mathrm{Y}_{11} \mathrm{R}$ to form heterodimers with other $\mathrm{P} 2 \mathrm{YRs}$, such as the $\mathrm{P}_{2} \mathrm{Y}_{1} \mathrm{R}$ [191].

The nucleotide analogue AMPaS (5' -AMPS) has been shown to be an effective P2 $\mathrm{Y}_{11} \mathrm{R}$ antagonist $[182,192]$. Suramin was a more potent antagonist of the $\mathrm{P} 2 \mathrm{Y}_{11} \mathrm{R}$ than reactive blue 2, whereas PPADS was completely inactive [182], and the antagonist potency and selectivity of suramin at the $\mathrm{P} 2 \mathrm{Y}_{11} \mathrm{R}$ over $\mathrm{P} 2 \mathrm{Y}_{1}, \mathrm{P}_{2} \mathrm{Y}_{2}$ and several ionotropic $\mathrm{P} 2 \mathrm{X}$ receptors could be further increased by substitution of methyl groups in suramin with fluorine [193]. The resulting suramin derivative, 8,8'-(carbonylbis(imino-3,1-phenylene-carbonylimino(4fluoro-3,1-phenylene)carbonylimino))bis-1,3,5-naphthalenetrisulfonic acid (NF157), was shown to prevent NAD+-induced human granulocyte migration through $\mathrm{P} 2 \mathrm{Y}_{11} \mathrm{R}$ antagonism [187]. Another non-nucleotide antagonist of the $\mathrm{P} 2 \mathrm{Y}_{11} \mathrm{R}, 4,4$ '-(carbonylbis(imino-3,1-(4methyl-phenylene)carbonylimino))bis-naphthalene-2,6-disulfonic acid (NF340), showed relative selectivity at the $\mathrm{P}_{2} \mathrm{Y}_{11} \mathrm{R}$ over the $\mathrm{P}_{2} \mathrm{Y}_{1}, \mathrm{P}_{2} \mathrm{Y}_{2}, \mathrm{P}_{2} \mathrm{Y}_{4}, \mathrm{P}_{2} \mathrm{Y}_{6}, \mathrm{P}_{2} \mathrm{Y}_{12}$, and $\mathrm{P} 2 \mathrm{X} 1-3$ receptors [185].

Although the rodent $\mathrm{P} 2 \mathrm{Y}_{11} \mathrm{R}$ gene has not been cloned, studies have suggested that $\mathrm{P} 2 \mathrm{Y}_{11} \mathrm{R}$ mRNA is expressed in the nucleus accumbens, parahippocampal gyrus, putamen and striatum of rats [1]. Additional studies using human $\mathrm{P} 2 \mathrm{Y}_{11} \mathrm{R}$ primers for $\mathrm{PCR}$ and antihuman $\mathrm{P} 2 \mathrm{Y}_{11} \mathrm{R}$ antibodies have localized the $\mathrm{P} 2 \mathrm{Y}_{11} \mathrm{R}$ to rat hippocampal pyramidal neurons and Purkinje cells in the adult rat cerebellum [21, 194]. Since a rodent $P 2 Y_{11} R$ gene has not been cloned, it is difficult to conclude that rodents express a P2 $\mathrm{Y}_{11} \mathrm{R}$. In human neutrophils, $\mathrm{P} 2 \mathrm{Y}_{11} \mathrm{R}$ activation has been shown to delay pathogen- or inflammatory mediator-induced apoptosis by a cAMP-dependent mechanism, suggesting a protective role for the $\mathrm{P} 2 \mathrm{Y}_{11} \mathrm{R}$ under neuroinflammatory conditions [190]. Similarly, in human monocytes, $\mathrm{P} 2 \mathrm{Y}_{11} \mathrm{R}$ activation inhibits toll-like receptor signaling by increasing cAMP production [189]. $\mathrm{P}_{2} \mathrm{Y}_{11}$ Rs in monocyte-derived dendritic cells also have been shown to regulate thrombospondin-1 secretion and inhibition of lipopolysaccharide-stimulated interleukin-12 release [185]. Thus, $\mathrm{P}_{2} \mathrm{Y}_{11} \mathrm{Rs}$ represent a promising therapeutic target for the treatment of neuroinflammatory diseases. 


\section{The P2Y $_{12}$ Receptor}

The $\mathrm{P}_{2} \mathrm{Y}_{12}$ receptor is activated by the endogenous agonist $\mathrm{ADP}\left(\mathrm{EC}_{50}=60 \mathrm{nM}\right)$, whereas 2-MeS-ATP and 2-MeS-ADP are more potent agonists [195]. Activation of the $\mathrm{P}_{2} \mathrm{Y}_{12} \mathrm{R}$ couples to both $G_{i}$ protein $[196,197]$ and $G_{o}$ protein $[196,198]$. Vesicle reconstitution of the $\mathrm{P} 2 \mathrm{Y}_{12} \mathrm{R}$ with different $\mathrm{G}$ proteins demonstrated that the $\mathrm{P} 2 \mathrm{Y}_{12} \mathrm{R}$ couples more effectively to $\mathrm{Ga}_{\mathrm{i} 2}$ than to $\mathrm{Ga}_{\mathrm{i} 1}$ and $\mathrm{Ga}_{\mathrm{i} 3}$, but does not couple to $\mathrm{Ga}_{\mathrm{o}}$ or $\mathrm{Ga}_{\mathrm{q}}$ proteins [199], suggesting that $\mathrm{G}_{\mathrm{o}}$ coupling may be due to formation of heteromeric receptors with other P2YRs.

A wide variety of $\mathrm{P} 2 \mathrm{Y}_{12} \mathrm{R}$ antagonists have been described, due to the central role of the $\mathrm{P} 2 \mathrm{Y}_{12} \mathrm{R}$ in the initiation of platelet aggregation [200-203]. The thienopyridine-ADP family of $\mathrm{P} 2 \mathrm{Y}_{12} \mathrm{R}$ antagonists include clopidogrel (methyl (+)-(S)-a-(2-chlorophenyl)-6,7-dihydrothieno[3,2-c]pyridine-5(4H)acetate sulfate; Plavix), ticlopidine (5-[(2chlorophenyl)methyl]-4,5,6,7-tetrahydrothieno[3, 2-c] pyridine hydrochloride; Ticlid) and prasugrel (5-[(1RS)-2-cyclopropyl-1-(2-fluorophenyl)-2-oxoethyl]-4,5,6,7tetrahydrothieno[3,2-c]pyridin-2-yl acetate hydrochloride; LY640 315; CS-747; Effient) [204, 205]. Ticlopidine was discovered over 30 years ago [204, 206] and the anti-platelet aggregation properties of clopidogrel were found decades before the cloning and identification of its endogenous target, the $\mathrm{P} 2 \mathrm{Y}_{12} \mathrm{R}$ [41, 207]. Following conversion to their respective active thiol derivatives in the liver, these orally active antagonists irreversibly bind to cysteine residues in the $\mathrm{P} 2 \mathrm{Y}_{12} \mathrm{R}$ and prevent ADP-induced platelet aggregation. In the case of clopidogrel, binding to the receptor disrupts the formation of lipid raft-associated $\mathrm{P} 2 \mathrm{Y}_{12} \mathrm{R}$ oligomers, the speculated functional form of the receptor, suggesting a possible mechanism of antagonism [208]. Therapeutic use of Plavix, Ticlid and Effient has been FDA-approved for prevention of a number of cardiovascular pathologies, including myocardial infarction, stroke, and peripheral artery disease [204].

Observations that ATP can act as a $\mathrm{P} 2 \mathrm{Y}_{12} \mathrm{R}$ antagonist [209] led to investigations of the antagonist activity of stable ATP analogs [41]. The ATP analog family of competitive P2 $\mathrm{Y}_{12} \mathrm{R}$ antagonists includes the AR compounds AR-C67085, AR-C66096 (2(propylthio)adenosine-5'-O-( $\beta, \gamma$-di-fluoromethylene)triphosphate), AR-C69931 (Cangrelor; N6-(2-methylthioethyl)-2-(3,3,3-trifluoropropylthio)-5'-adenylic acid) $[184,210,211]$ and the orally active non-phosphorylated AstraZeneca compound AZD6140 (Ticagrelor; Brillinta; (1S,2S,3R,5S)-3-[7-[[(1R,2S)-2-(3,4-difluorophenyl) cyclopropyl]amino]-5(propylthio)-3H-1,2,3-triazolo[4,5-d]pyrimidin-3-yl]-5-(2-hydroxyethoxy)-1,2cyclopentanediol) [212]. Similar to AZD6140, the orally active drug PRT-060128 (Elinogrel; N-[(5-chlorothiophen-2-yl)sulfonyl]-N'-(4-[6-fluoro-7-(methylamino)-2, 4dioxo-1, 4-dihydroquinazolin-3(2H)-yl]phenyl)urea) was shown to be an effective reversible antagonist of $\mathrm{P} 2 \mathrm{Y}_{12} \mathrm{R}$ [213]. While Elinogrel failed to make it out of Phase II clinical trials, Brillinta (AZD6140) has been approved by the FDA for prevention of adverse cardiovascular events. Additional $\mathrm{P} 2 \mathrm{Y}_{12} \mathrm{R}$ antagonists include the tricyclic benzothiazolo[2,3-c]thiadiazine derivative CT50547 [214], BX-667 ((S)-4-((4-[1(ethoxycarbonyl)-1-methylethoxy]-7-methyl-2-quinolyl)carbamoyl)-5-[4-(ethoxycarbonyl) piperazin-1-yl]-5-oxopentanoic acid) [215], MRS2395 (2,2-dimethyl-propionic acid 3-(2chloro-6-methylaminopurin-9-yl)-2-(2,2-dimethyl-propionyloxymethyl)-propylester) [216], 
and the reactive blue 2 analog PSB0739 (1-amino-4-[4-phenylamino-3-

sulfophenylamino]-9,10-dioxo-9,10-dihydroanthracene-2-sulfonate) [217].

Besides in platelets, the $\mathrm{P} 2 \mathrm{Y}_{12} \mathrm{R}$ is highly expressed in astrocytes [207, 218], including in the rat nucleus accumbens of the cortex and cerebellum [14, 113, 219] and in rat hippocampal pyramidal neurons [21]. P2 $\mathrm{Y}_{12}$ Rs have also been shown to be expressed in rat brain microglial cells where they are suggested to regulate microglial cell migration to neurons in response to injury [220] and directional migration of glial cell processes to axons during premyelination [221]. Accordingly, transgenic mice with selective deletion of the $\mathrm{P} 2 \mathrm{Y}_{12} \mathrm{R}$ show reduced directional microglial branch extension in vivo, as compared to control mice who exhibited significantly less $\mathrm{P} 2 \mathrm{Y}_{12} \mathrm{R}$ expression in activated microglia than in resting microglia, suggesting a role for the $\mathrm{P}_{2} \mathrm{Y}_{12} \mathrm{R}$ in early stages of CNS injury and a potential therapeutic pathway that may be exploited for treatment of neurodegenerative diseases [222]. However, another study indicated that expression of the $\mathrm{P}_{2} \mathrm{Y}_{12} \mathrm{R}$ in the CNS is limited to oligodendrocytes [221].

The $\mathrm{P} 2 \mathrm{Y}_{12} \mathrm{R}$ has been shown to increase the proliferation of glioma cells by the $\mathrm{Ga}_{\mathrm{i}^{-}}$ dependent activation of RhoA, ROCK and PKC $\zeta$, independent of ERK1/2 activation [197], although $\mathrm{P} 2 \mathrm{Y}_{12} \mathrm{R}$-mediated proliferation of Chinese hamster ovary cells was linked to activation of PI3K/Akt and ERK1/2, whereas a separate PTX-insensitive pathway leading to RhoA and ROCK activation was found to regulate actin cytoskeletal reorganization [196]. Interestingly, the $\mathrm{P} 2 \mathrm{Y}_{12} \mathrm{R}$ has been shown to play a role in glioma progression and malignancy where antagonism of the receptor with clopidogrel retarded the growth of NTPDase2-overexpressing gliomas in rats [223]. The $\mathrm{P}_{2} \mathrm{Y}_{12} \mathrm{R}$ is also expressed in mouse dendritic cells, where it mediates the $\mathrm{G}_{\mathrm{o}}$-dependent macropinocytosis of antigens [198]. Reconstitution of the $\mathrm{P} 2 \mathrm{Y}_{12} \mathrm{R}$ with different $\mathrm{G}$ proteins indicates that the $\mathrm{P} 2 \mathrm{Y}_{12} \mathrm{R}$ preferentially couples to $\mathrm{Ga}_{\mathrm{i} 2}$-dependent inhibition of adenylyl cyclase and the activation of PI3K, Akt, Rap1b and potassium channels, in comparison to $\mathrm{Ga}_{\mathrm{i} 1}$ and $\mathrm{Ga}_{\mathrm{i} 3}$, and does not couple to $\mathrm{Ga}_{\mathrm{o}}$ or $\mathrm{Ga}_{\mathrm{q}}$ proteins [199].

\section{The $\mathrm{P} \mathrm{Y}_{13}$ Receptor}

The $\mathrm{P}_{2} \mathrm{Y}_{13} \mathrm{R}$ is activated by ADP with an $\mathrm{EC}_{50}=60 \mathrm{nM}$ [224], and 2-MeS-ADP has been shown to be a potent agonist [225]. The $\mathrm{P}_{2} \mathrm{Y}_{13} \mathrm{R}$ is activated more potently by 2-MeS-ADP, adenosine 5'-O-2-(thio)diphosphate (ADP $\beta S$ ) and 2-MeS-ATP than by the endogenous agonist ADP [224]. BzATP also has been shown to be a $\mathrm{P} 2 \mathrm{Y}_{13} \mathrm{R}$ agonist in rat cerebellar astrocytes [226]. Similar to the ADP-activated $P 2 Y_{12} R$, the $P 2 Y_{13} R$ couples to $G_{i}$-mediated inhibition of adenylyl cyclase [224], but can also couple to $\mathrm{G}_{\mathrm{s}}$-dependent activation of adenylyl cyclase at high agonist concentrations [227]. The P2 $\mathrm{Y}_{13} \mathrm{R}$, like other P2YRs, can activate RhoA and ROCK [228, 229], suggesting that it will contribute to cytoskeletal rearrangements induced by adenine nucleotides in cells of the CNS.

The P2 $\mathrm{Y}_{12} \mathrm{R}$ antagonists AR-C69931 and AR-C67085 are potent non-competitive antagonists of the $\mathrm{P}_{2} \mathrm{Y}_{13} \mathrm{R}$ with $\mathrm{IC}_{50}$ 's $=4 \mathrm{nM}$ and $1 \mathrm{nM}$, respectively, whereas diadenosine tetraphosphate, reactive blue 2, suramin and PPADS also antagonized the effects of ADP at the P2 $\mathrm{Y}_{13} \mathrm{R}$ [227]. Derivatives of PPADS, including the 2-chloro-5-nitro (MRS2211) and 4chloro-3-nitro (MRS2603) analogues, were significantly more potent $\mathrm{P}_{2} \mathrm{Y}_{13} \mathrm{R}$ antagonists 
than PPADS, whereas MRS2211 showed significant specificity for antagonism of the $\mathrm{P}_{2} \mathrm{Y}_{13} \mathrm{R}$, as compared to the $\mathrm{P}_{2} \mathrm{Y}_{1}$ and $\mathrm{P} 2 \mathrm{Y}_{12}$ receptors [230]. MRS2211 was also shown to inhibit BzATP-induced increases in the intracellular calcium concentration in cerebellar astrocytes through antagonism of the $\mathrm{P} 2 \mathrm{Y}_{13} \mathrm{R}$ [226].

$\mathrm{P} 2 \mathrm{Y}_{13} \mathrm{Rs}$ are expressed in astrocytes and glutamatergic neurons and have been shown, along with $\mathrm{P}_{2} \mathrm{Y}_{1}$ and $\mathrm{P} 2 \mathrm{Y}_{12}$ receptors, to enhance $\mathrm{Na}^{+}$and $\mathrm{Cl}^{-}$-dependent glycine transport in the synaptic cleft [231]. The $\mathrm{P}_{2} \mathrm{Y}_{13} \mathrm{R}$ also has been suggested to enhance cell survival by increasing the PI3K/Akt-dependent translocation of the glycogen synthase kinase-3 substrate $\beta$-catenin to the nucleus to promote the expression of cell survival genes [232]. Thus, the $\mathrm{P} 2 \mathrm{Y}_{13} \mathrm{R}$ fits the general profile of the P2YR family with respect to their likely roles in the regulation of protective or reparative processes in the CNS.

\section{The $\mathrm{P}_{2} \mathrm{Y}_{14}$ Receptor}

The $\mathrm{P} 2 \mathrm{Y}_{14} \mathrm{R}$ is unique among the $\mathrm{P} 2 \mathrm{YR}$ family in its ability to be activated by UDP-glucose $\left(\mathrm{EC}_{50}=80 \mathrm{nM}\right)$, UDP-galactose $\left(\mathrm{EC}_{50}=125 \mathrm{nM}\right)$, UDP-glucuronic acid $\left(\mathrm{EC}_{50}=370 \mathrm{nM}\right)$ and UDP-N-acetylglucosamine $\left(\mathrm{EC}_{50}=710 \mathrm{nM}\right)$, but not by adenine or uridine nucleotides (e.g., ATP, ADP, UTP and UDP) [225, 233, 234]. The 2-thio-modified UDP-glucose analog MRS2690 (diphosphoric acid 1-alpha-d-glucopyranosyl ester 2-[(2-thio)uridin-5"-yl] ester) is a potent $\mathrm{P} 2 \mathrm{Y}_{14} \mathrm{R}$ agonist [235]. Modifications in the uracil moieties of $\mathrm{P} 2 \mathrm{Y}_{14} \mathrm{R}$ agonists abolish activity [236]. The $\mathrm{P} 2 \mathrm{Y}_{14} \mathrm{R}$ has been shown to couple to $\mathrm{G}_{\mathrm{i} / \mathrm{o}}$ protein activation [235].

The effects of $\mathrm{P}_{2} \mathrm{Y}_{14} \mathrm{R}$ activation and its therapeutic relevance in the treatment of CNS disorders are largely unknown. The $\mathrm{P} 2 \mathrm{Y}_{14} \mathrm{R}$ is expressed in human astrocytes [237] and in rat cortical and cerebellar astrocytes [14, 219]. $\mathrm{P} 2 \mathrm{Y}_{14} \mathrm{R}$ expression was increased in rat primary microglial cells in response to bacterial lipopolysaccharide [66], suggesting a role during neuroinflammation. $\mathrm{P} 2 \mathrm{Y}_{14} \mathrm{Rs}$ expressed in immature dendritic cells have been suggested to have an immunoregulatory function [23, 238]. $\mathrm{P} 2 \mathrm{Y}_{14} \mathrm{R}$ activation also can increase the production of chemokines and cytokines involved in the recruitment of neutrophils, including IL-8, macrophage inflammatory protein-2 and keratinocyte-derived cytokine [239], and the $\mathrm{P} 2 \mathrm{Y}_{14} \mathrm{R}$ has been shown to play a role in muscle contractility in rats and gastric function in mice [240].

\section{CONSIDERATIONS FOR THE THERAPEUTIC USE OF P2Y RECEPTOR AGONISTS AND ANTAGONISTS}

\section{Blood-Brain Barrier}

P2Y receptors in the CNS, particularly in the brain, represent promising targets in the treatment of neuroinflammatory and neurodegenerative diseases and there is a critical need for the development of more stable and selective P2Y receptor agonists/antagonists. Of greatest need are drugs that can cross the blood-brain barrier (BBB), which represents a major obstacle to the efficient delivery into the brain of drugs designed to mimic the negatively-charged structure of nucleotides that is known to be critical for agonist binding to P2YRs. The BBB is composed of cerebral endothelial cells, pericytes and astrocytes that 
regulate the flow of proteins and macromolecules into the CNS [241]. Potential therapies involving P2YR agonists and antagonists that target the CNS must consider modes of transport across the BBB, which for small polar molecules such as nucleotides likely can occur via plasma membrane transport proteins, receptor- or adsorptive-mediated transcytosis, or passage through endothelial cell tight junctions [241]. Studies have shown that $\mathrm{P} 2 \mathrm{Y}$ receptors and $\mathrm{P} 1$ adenosine receptors are able to modulate the permeability of the blood brain barrier [149, 242]. Remarkably, treatment of murine models with the FDA approved $\mathrm{A}_{2 \mathrm{~A}}$ adenosine receptor agonist regadenoson (Lexiscan) can increase $\mathrm{BBB}$ permeability to intravenously injected macromolecules, including anti- $\beta$-amyloid antibody, through a mechanism involving alterations in endothelial cell tight junctions [243]. Recent studies, including unpublished studies in our lab [Erb et al., submitted manuscript], indicate that activation of $\mathrm{P}_{2} \mathrm{Y}_{2} \mathrm{Rs}$ in vascular endothelium can increase the transendothelial permeability of leukocytes [109, 244, 245], suggesting that $\mathrm{P} 2 \mathrm{Y}_{2} \mathrm{R}$ activation in brain microvessels that comprise the BBB may be a novel target for increasing drug delivery to the brain. It seems likely that any $\mathrm{P} 2 \mathrm{Y}$ receptor agonists/antagonists targeted to the CNS must possess properties that are conducive to passage across the BBB or these compounds will have to be administered along with modulators of barrier function.

\section{P2Y Receptor Interactions}

Another important consideration in the targeting of P2Y receptors for therapeutic treatments is whether the functions being affected are a product of homomeric P2YR activation or are regulated by heteromeric interactions between different P2YR subtypes. For example, in vitro experiments have suggested that the $\mathrm{P} 2 \mathrm{Y}_{11} \mathrm{R}$ can form a hetero-oligomeric complex with the $\mathrm{P} 2 \mathrm{Y}_{1} \mathrm{R}$ which is internalized upon activation with ATP or 2-MeS-ADP and has a distinct agonist/antagonist profile that differs from both $\mathrm{P} 2 \mathrm{Y}_{1} \mathrm{R}$ and $\mathrm{P} 2 \mathrm{Y}_{11} \mathrm{R}$ [246]. Heteromeric interactions between $\mathrm{P} 2 \mathrm{Y}$ receptors and $\mathrm{P} 1$ adenosine receptors also have been reported. The $\mathrm{P} 2 \mathrm{Y}_{1} \mathrm{R}$ has been shown to form functional hetero-oligomers with the A1 receptor (A1R) both in vitro [247] and in the rat cortex, hippocampus, and cerebellum [248, 249]. While the physiological contributions of this heteromeric $\mathrm{P}_{2} \mathrm{Y}_{1}: \mathrm{A} 1$ receptor are unknown, it has been demonstrated that addition of the $\mathrm{P} 2 \mathrm{Y}_{1} \mathrm{R}$ agonist 2-MeS-ADP decreases A1R-mediated functional responses [250], whereas addition of the A1R agonist $\mathrm{N}^{6}$-cyclohexyladenosine enhances the 2-MeS-ADP-induced G protein coupling to $\mathrm{P} 2 \mathrm{Y}_{1} \mathrm{Rs}$ [248]. In addition, multiple homomeric $\mathrm{P} 2 \mathrm{Y}$ and $\mathrm{P} 2 \mathrm{X}$ receptor subtypes in a single cell type are likely to be activated simultaneously by the same nucleoside triphosphate (i.e., ATP or UTP) or breakdown products (i.e., ADP or UDP) and, therefore, may interact downstream of receptor activation via overlapping signal transduction pathways. Considering that multiple cell types that comprise the brain are likely to have a cell-specific complement of P2 receptor subtypes that are differentially expressed under a variety of physiological and pathophysiological conditions, it is very difficult to assess the contributions in vivo of individual P2Y receptor subtypes in specific cell types to neurological responses to released nucleotides in the brain. Although the deletion of specific P2YR subtypes in mice has helped reveal the physiological role of some P2YR subtypes, the use of these mouse models to evaluate P2YR interactions is in its infancy and more information is available from in vitro studies using receptor antagonists. For example, a recent study has shown that ADP increases axonal elongation in cultured rat hippocampal neurons [72]. However, ADP can 
activate multiple $\mathrm{P} 2 \mathrm{Y}$ receptors in neurons, including the $\mathrm{P} 2 \mathrm{Y}_{1} \mathrm{R}$ and the $\mathrm{P} 2 \mathrm{Y}_{13} \mathrm{R}$. Through the use of selective P2YR antagonists (MRS2179 for the P2Y ${ }_{1} R$ and MRS2211 for the $\mathrm{P} 2 \mathrm{Y}_{13} \mathrm{R}$ ) and the suppression of $\mathrm{P} 2 \mathrm{Y}_{1} \mathrm{R}$ or $\mathrm{P} 2 \mathrm{Y}_{13} \mathrm{R}$ expression in neurons with siRNA, it was shown that axonal growth in response to ADP was coordinately regulated by both $\mathrm{P} 2 \mathrm{Y}_{1} \mathrm{R}$ and $\mathrm{P} 2 \mathrm{Y}_{13} \mathrm{R}$ activation and their opposing effects on the activation of adenylate cyclase 5. Whereas activation of adenylyl cyclase 5 by the $P 2 Y_{1} R$ stimulated axonal elongation likely via $\mathrm{G}_{\mathrm{q}}$-dependent PI3K/Akt activation, $\mathrm{P} 2 \mathrm{Y}_{13} \mathrm{R}$-mediated $\mathrm{G}_{\mathrm{i}}$ activation inhibited adenylate cyclase 5 activity and axonal elongation. Furthermore, antagonism of the P2X7R also increased axonal elongation by modulating adenylate cyclase 5 activity [72]. The complexity of axonal elongation in response to ATP or ADP, as demonstrated by this study, accurately depicts the challenges of targeting P2Y receptors for therapy.

Alternatively, this complexity could be advantageous in that a desired physiological response (e.g., axonal growth) can be targeted through activation or inhibition of individual P2YR subtypes.

Indirect interactions between the $\mathrm{G}_{\mathrm{q}}$ protein-coupled $\mathrm{P} 2 \mathrm{Y}_{2}$ receptor and the ionotropic $\mathrm{P} 2 \mathrm{X} 7$ receptor have been suggested to mediate neuroprotective responses in neuroinflammatory diseases, such as $\mathrm{AD}[35,105,251]$. Under inflammatory conditions, such as those found in AD [114-115], ATP is released from apoptotic cells into the extracellular milieu where it activates the $\mathrm{P} 2 \mathrm{X} 7 \mathrm{R}$ to induce the processing and release of the proinflammatory cytokine IL-1 $\beta[4,252,253]$. In response to IL-1 $\beta, \mathrm{P}_{2} \mathrm{Y}_{2} \mathrm{R}$ expression has been shown to be upregulated in rat [16] and mouse [Weisman et al., submitted manuscript] primary cortical neurons through a NF- $\kappa B$-dependent mechanism $[16,116]$. As described above, activation of the $\mathrm{P} 2 \mathrm{Y}_{2} \mathrm{R}$ has been shown to induce neuroprotective responses, such as stimulation of the non-amyloidogenic processing of amyloid precursor protein to generate soluble APPa, rather than the neurotoxic beta-amyloid peptide [130], and the stimulation of neurite outgrowth [254; Weisman et al., submitted manuscript]. Additionally, $\mathrm{P} 2 \mathrm{Y}_{2} \mathrm{R}$ activation in microglial cells has been shown to increase uptake and degradation of neurotoxic $A \beta_{1-42}$ [24]. IL-1 $\beta$ also has been shown to be elevated in the brains of AD patients $[114,115]$ and the $\mathrm{P} 2 \mathrm{X} 7 \mathrm{R}$ is upregulated around $\mathrm{A} \beta$ plaques in an $\mathrm{AD}$ mouse model [255]. These findings suggest that a cascade of events starting with tissue damage can induce the activation of $\mathrm{P} 2 \mathrm{X} 7 \mathrm{Rs}$ and IL-1 $\beta$ receptors to increase the expression of $\mathrm{P} 2 \mathrm{Y}_{2} \mathrm{Rs}$, thereby counteracting a neurodegenerative response (i.e., IL-1 $\beta$ and ATP release) by enhancing a neuroprotective pathway (i.e., $\mathrm{P} 2 \mathrm{Y}_{2} \mathrm{R}$-mediated neurite extension and neurotoxic $\mathrm{A} \beta$ elimination).

\section{CONCLUSION}

Recent research has demonstrated the existence of $8 \mathrm{P} 2 \mathrm{Y}$ receptor subtypes (i.e., P2 $\mathrm{Y}_{1,2,4,6,11-14)}$ that are expressed in cells of the CNS (e.g., neurons, astrocytes, microglia and endothelial cells). When ATP, UTP and other nucleotides are released from cells in the CNS under a variety of conditions, including neurotransmission, apoptosis, inflammation and cell damage, the activation of these $\mathrm{P} 2 \mathrm{Y}$ receptor subtypes stimulates intracellular signal transduction pathways that regulate physiological and pathological responses, including neurite outgrowth, glial cell migration and proliferation, glial cell-mediated phagocytosis, amyloid precursor protein processing, gene expression, cytokine release and diapedesis. These P2Y receptor-mediated responses to extracellular nucleotides are induced by the 
direct or indirect activation of $\mathrm{G}$ proteins (e.g., $\mathrm{G}_{\mathrm{s}}, \mathrm{G}_{\mathrm{i}}, \mathrm{G}_{\mathrm{q}}$, and $\mathrm{G}_{12 / 13}$ ) and the modulation of intracellular protein activities, including adenylyl cyclase, phospholipase $\mathrm{C}$, small GTPases, matrix metalloproteases, integrins, growth factor receptors and protein kinases. Current data suggest that $\mathrm{P} 2 \mathrm{Y}$ receptor activation in the CNS, particularly in the brain, can serve a neuroprotective role. Therefore, novel agonists and antagonists are being actively pursued that are relatively selective for single P2Y receptor subtypes and may potentially have a wide variety of therapeutic applications in the treatment of pathologies of the CNS.

\section{ACKNOWLEDGEMENTS}

This work was supported by NIH grants AG018357, DE017591 and DE07389.

\section{ABBREVIATIONS}

2-MeS-ADP

2-MeS-ATP

AD

ADP

ATP

APP

BBB

cAMP

CNS

GTP

IL-1 $\beta$

$\mathbf{I P}_{3}$

P2YR

PCR

PKC

PLC

PPADS

UDP

UTP
2-Methylthio-ADP

2-Methylthio-ATP

Alzheimer's disease

Adenosine 5'-diphosphate

Adenosine 5'-triphosphate

Amyloid precursor protein

Blood-brain barrier

Cyclic adenosine 3-,5'-monophosphate

Central nervous system

Guanosine 5'-triphosphate

Interleukin- $1 \beta$

Inositol 1,4,5-trisphosphate

P2Y receptor

Polymerase chain reaction

Protein kinase $\mathrm{C}$

Phospholipase C

Pyridoxal-phosphate-6-azophenyl-2',4'-disulphonic acid

Uridine 5'-diphosphate

Uridine 5'-triphosphate

\section{REFERENCES}

[1]. Burnstock G, Knight GE. Cellular distribution and functions of P2 receptor subtypes in different systems. Int. Rev. Cytol. 2004; 240:31-304. [PubMed: 15548415]

[2]. Sak K, Webb TE. A retrospective of recombinant P2Y receptor subtypes and their pharmacology. Arch. Biochem. Biophys. 2002; 397(1):131-136. [PubMed: 11747319] 
[3]. Abbracchio MP, Burnstock G, Boeynaems JM, Barnard EA, Boyer JL, Kennedy C, Knight GE, Fumagalli M, Gachet C, Jacobson KA, Weisman GA. International Union of Pharmacology LVIII: update on the P2Y G protein-coupled nucleotide receptors: from molecular mechanisms and pathophysiology to therapy. Pharmacol. Rev. 2006; 58(3):281-341. [PubMed: 16968944]

[4]. Bodin P, Burnstock G. Purinergic signalling: ATP release. Neurochem. Res. 2001; 26(8-9):959969. [PubMed: 11699948]

[5]. Fields RD. Nonsynaptic and nonvesicular ATP release from neurons and relevance to neuron-glia signaling. Semin. Cell. Dev. Biol. 2011; 22(2):214-219. [PubMed: 21320624]

[6]. Chekeni FB, Elliott MR, Sandilos JK, Walk SF, Kinchen JM, Lazarowski ER, Armstrong AJ, Penuela S, Laird DW, Salvesen GS, Isakson BE, Bayliss DA, Ravichandran KS. Pannexin 1 channels mediate 'find-me' signal release and membrane permeability during apoptosis. Nature. 2010; 467(7317):863-867. [PubMed: 20944749]

[7]. Bao L, Locovei S, Dahl G. Pannexin membrane channels are mechanosensitive conduits for ATP. FEBS Lett. 2004; 572(1-3):65-68. [PubMed: 15304325]

[8]. Seror C, Melki MT, Subra F, Raza SQ, Bras M, Saidi H, Nardacci R, Voisin L, Paoletti A, Law F, Martins I, Amendola A, Abdul-Sater AA, Ciccosanti F, Delelis O, Niedergang F, Thierry S, Said-Sadier N, Lamaze C, Metivier D, Estaquier J, Fimia GM, Falasca L, Casetti R, Modjtahedi N, Kanellopoulos J, Mouscadet JF, Ojcius DM, Piacentini M, Gougeon ML, Kroemer G, Perfettini JL. Extracellular ATP acts on P2Y2 purinergic receptors to facilitate HIV-1 infection. J. Exp. Med. 2011; 208(9):1823-1834. [PubMed: 21859844]

[9]. Bargiotas P, Krenz A, Hormuzdi SG, Ridder DA, Herb A, Barakat W, Penuela S, von Engelhardt J, Monyer H, Schwaninger M. Pannexins in ischemia-induced neurodegeneration. Proc. Natl. Acad. Sci. USA. 2011; 108(51):20772-20777. [PubMed: 22147915]

[10]. Burnstock G, Dumsday B, Smythe A. Atropine resistant excitation of the urinary bladder: the possibility of transmission via nerves releasing a purine nucleotide. Br. J. Pharmacol. 1972; 44(3):451-461. [PubMed: 4339250]

[11]. Burnstock G. Purinergic signalling: past, present and future. Braz. J. Med. Biol. Res. 2009; 42(1): 3-8. [PubMed: 18853040]

[12]. Neary JT, Zimmermann H. Trophic functions of nucleotides in the central nervous system. Trends Neurosci. 2009; 32(4):189-198. [PubMed: 19282037]

[13]. Burnstock G, Verkhratsky A. Long-term(trophic) purinergic signalling: purinoceptors control cell proliferation, differentiation and death. Cell Death Dis. 2010; 1:e9. [PubMed: 21364628]

[14]. Fumagalli M, Brambilla R, D'Ambrosi N, Volonté C, Matteoli M, Verderio C, Abbracchio MP. Nucleotide-mediated calcium signaling in rat cortical astrocytes: Role of P2X and P2Y receptors. Glia. 2003; 43(3):218-303. [PubMed: 12898701]

[15]. Kreda SM, Seminario-Vidal L, Heusden C, Lazarowski ER. Thrombin-promoted release of UDPglucose from human astrocytoma cells. Br. J. Pharmacol. 2008; 153(7):1528-1537. [PubMed: 18204471]

[16]. Kong Q, Peterson TS, Baker O, Stanley E, Camden J, Seye CI, Erb L, Simonyi A, Wood WG, Sun GY, Weisman GA. Interleukin- $1 \beta$ enhances nucleotide-induced and a-secretase-dependent amyloid precursor protein processing in rat primary cortical neurons via up-regulation of the P2Y 2 receptor. J. Neurochem. 2009; 109(5):1300-1310. [PubMed: 19317852]

[17]. Espada S, Ortega F, Molina-Jijón E, Rojo AI, Pérez-Sen R, Pedraza-Chaverri J, Miras-Portugal MT, Cuadrado A. The purinergic $\mathrm{P}_{2} \mathrm{Y}_{13}$ receptor activates the $\mathrm{Nrf} 2 / \mathrm{HO}-1$ axis and protects against oxidative stress-induced neuronal death. Free Radic. Biol. Med. 2010; 49(3):416-426. [PubMed: 20447456]

[18]. Brandenburg LO, Jansen S, Wruck CJ, Lucius R, Pufe T. Antimicrobial peptide rCRAMP induced glial cell activation through P2Y receptor signalling pathways. Mol. Immunol. 2010; 47(10):1905-1913. [PubMed: 20392497]

[19]. Köles L, Leichsenring A, Rubini P, Illes P. P2 receptor signaling in neurons and glial cells of the central nervous system. Adv. Pharmacol. 2011; 61:441-493. [PubMed: 21586367]

[20]. Rodrigues RJ, Almeida T, de Mendonca A, Cunha RA. Interaction between P2X and nicotinic acetylcholine receptors in glutamate nerve terminals of the rat hippocampus. J. Mol. Neurosci. 2006; 30(1-2):173-176. [PubMed: 17192669] 
[21]. Rodrigues RJ, Almeida T, Richardson PJ, Oliveira CR, Cunha RA. Dual presynaptic control by ATP of glutamate release via facilitatory P2X1, P2X2/3, and P2X3 and inhibitory P2Y1, P2Y2, and/or P2Y4 receptors in the rat hippocampus. J. Neurosci. 2005; 25(27):6286-6295. [PubMed: 16000618]

[22]. Sperlagh B, Illes P. Purinergic modulation of microglial cell activation. Purinergic Signal. 2007; 3(1-2):117-127. [PubMed: 18404425]

[23]. Fischer W, Krügel U. P2Y receptors: focus on structural, pharmacological and functional aspects in the brain. Curr. Med. Chem. 2007; 14(23):2429-2455. [PubMed: 17979698]

[24]. Kim HJ, Ajit D, Peterson TS, Wang Y, Camden JM, Wood WG, Sun GY, Erb LE, Petris M, Weisman GA. Nucleotides released from fibrillar $A \beta_{1-42}$-treated microglial cells increase cell migration and fibrillar $A \beta_{1-42}$ uptake through $\mathrm{P} 2 \mathrm{Y}_{2}$ receptor activation. J. Neurochem. 2012

[25]. Kuboyama K, Harada H, Tozaki-Saitoh H, Tsuda M, Ushijima K, Inoue K. Astrocytic P2Y 1 receptor is involved in the regulation of cytokine/chemokine transcription and cerebral damage in a rat model of cerebral ischemia. J. Cereb. Blood Flow Metab. 2011; 31(9):1930-1941. [PubMed: 21487414]

[26]. Nguyen T, Erb L, Weisman GA, Marchese A, Heng HH, Garrad RC, George SR, Turner JT, O'Dowd BF. Cloning, expression, and chromosomal localization of the human uridine nucleotide receptor gene. J. Biol. Chem. 1995; 270(52):30845-30848. [PubMed: 8537335]

[27]. Erb L, Garrad R, Wang Y, Quinn T, Turner JT, Weisman GA. Site-directed mutagenesis of $P_{2 U}$ purinoceptors. Positively charged amino acids in transmembrane helices 6 and 7 affect agonist potency and specificity. J. Biol. Chem. 1995; 270(9):4185-4188. [PubMed: 7876172]

[28]. Brinson AE, Harden TK. Differential regulation of the uridine nucleotide-activated P2Y4 and P2Y6 receptors. SER-333 and SER-334 in the carboxyl terminus are involved in agonistdependent phosphorylation desensitization and internalization of the P2Y4 receptor. J. Biol. Chem. 2001; 276(15):11939-11948. [PubMed: 11114308]

[29]. Flores RV, Hernandez-Perez MG, Aquino E, Garrad RC, Weisman GA, Gonzalez FA. Agonistinduced phosphorylation and desensitization of the $\mathrm{P}_{2} \mathrm{Y}_{2}$ nucleotide receptor. Mol. Cell. Biochem. 2005; 280(1-2):35-45. [PubMed: 16311903]

[30]. Shaver SR. P2Y receptors: biological advances and therapeutic opportunities. Curr. Opin. Drug Discov. Devel. 2001; 4(5):665-670.

[31]. Jiang Q, Guo D, Lee BX, Van Rhee AM, Kim YC, Nicholas RA, Schachter JB, Harden TK, Jacobson KA. A mutational analysis of residues essential for ligand recognition at the human P2Y1 receptor. Mol. Pharmacol. 1997; 52(3):499-507. [PubMed: 9281613]

[32]. Jacobson KA, Hoffmann C, Kim YC, Camaioni E, Nandanan E, Jang SY, Guo DP, Ji XD, von Kugelgen I, Moro S, Ziganshin AU, Rychkov A, King BF, Brown SG, Wildman SS, Burnstock G, Boyer JL, Mohanram A, Harden TK. Molecular recognition in P2 receptors: ligand development aided by molecular modeling and mutagenesis. Prog. Brain Res. 1999; 120:119_ 132. [PubMed: 10550992]

[33]. Ivanov AA, Costanzi S, Jacobson KA. Defining the nucleotide binding sites of P2Y receptors using rhodopsin-based homology modeling. J. Comput. Aided. Mol. Des. 2006; 20(7-8):417426. [PubMed: 17016747]

[34]. Costanzi S, Mamedova L, Gao ZG, Jacobson KA. Architecture of P2Y nucleotide receptors: structural comparison based on sequence analysis, mutagenesis, and homology modeling. J. Med. Chem. 2004; 47(22):5393-5404. [PubMed: 15481977]

[35]. Weisman GA, Camden JM, Peterson TS, Ajit D, Woods LT, Erb L. P2 receptors for extracellular nucleotides in the central nervous system: role of $\mathrm{P} 2 \mathrm{X} 7$ and $\mathrm{P}_{2} \mathrm{Y}_{2}$ receptor interactions in neuroinflammation. Mol. Neurobiol. 2012 in press.

[36]. Erb L, Liao Z, Seye CI, Weisman GA. P2 receptors: intracellular signaling. Pflugers Arch. 2006; 452(5):552-562. [PubMed: 16586093]

[37]. Shenoy SK, Lefkowitz RJ. $\beta$-Arrestin-mediated receptor trafficking and signal transduction. Trends Pharmacol. Sci. 2011; 32(9):521-533. [PubMed: 21680031]

[38]. Hoffmann C, Ziegler N, Reiner S, Krasel C, Lohse MJ. Agonist-selective, receptor-specific interaction of human P2Y receptors with beta-arrestin-1 and -2. J. Biol. Chem. 2008; 283(45): 30933-30941. [PubMed: 18703513] 
[39]. Palmer RK, Boyer JL, Schachter JB, Nicholas RA, Harden TK. Agonist action of adenosine triphosphates at the human P2Y1 receptor. Mol. Pharmacol. 1998; 54(6):1118-1123. [PubMed: 9855642]

[40]. Waldo GL, Harden TK. Agonist binding and Gq-stimulating activities of the purified human P2Y1 receptor. Mol. Pharmacol. 2004; 65(2):426-436. [PubMed: 14742685]

[41]. Jacobson KA, Boeynaems JM. P2Y nucleotide receptors: promise of therapeutic applications. Drug Discov. Today. 2010; 15(13-14):570-578. [PubMed: 20594935]

[42]. Ravi RG, Kim HS, Servos J, Zimmermann H, Lee K, Maddileti S, Boyer JL, Harden TK, Jacobson KA. Adenine nucleotide analogues locked in a Northern methanocarba conformation: enhanced stability and potency as $\mathrm{P}_{2} \mathrm{Y}_{1}$ receptor agonists. J. Med. Chem. 2002; 45(10):20902100. [PubMed: 11985476]

[43]. Nahum V, Zündorf G, Lévesque SA, Beaudoin AR, Reiser G, Fischer B. Adenosine 5'-O-(1boranotriphosphate) derivatives as novel P2Y $\mathrm{Y}_{1}$ receptor agonists. J. Med. Chem. 2002; 45(24): 5384-5396. [PubMed: 12431066]

[44]. Eliahu SE, Camden J, Lecka J, Weisman GA, Sevigny J, Gelinas S, Fischer B. Identification of hydrolytically stable and selective $\mathrm{P}_{2} \mathrm{Y}_{1}$ receptor agonists. Eur. J. Med. Chem. 2009; 44(4): 1525-1536. [PubMed: 18760862]

[45]. Nahum V, Tulapurkar M, Lévesque SA, Sévigny J, Reiser G, Fischer B. Diadenosine and diuridine poly(borano)phosphate analogues: synthesis, chemical and enzymatic stability, and activity at P2Y1 and P2Y2 receptors. J. Med. Chem. 2006; 49(6):1980-1990. [PubMed: 16539385]

[46]. Yelovitch S, Camden J, Weisman GA, Fischer B. Boranophosphate isoster controls P2Y-receptor subtype selectivity and metabolic stability of dinucleoside polyphosphate analogues. J. Med. Chem. 2012; 55(1):437-448. [PubMed: 22107038]

[47]. Eliahu S, Barr HM, Camden J, Weisman GA, Fischer B. A novel insulin secretagogue based on a dinucleoside polyphosphate scaffold. J. Med. Chem. 2010; 53(6):2472-2481. [PubMed: 20175517]

[48]. Eliahu S, Martín-Gil A, Perez de Lara MJ, Pintor J, Camden J, Weisman GA, Lecka J, Sévigny J, Fischer B. 2-MeS-beta,gamma-CCl2-ATP is a potent agent for reducing intraocular pressure. J. Med. Chem. 2010; 53(8):3305-3319. [PubMed: 20337495]

[49]. Léon C, Hechler B, Vial C, Leray C, Cazenave JP, Gachet C. The P2Y1 receptor is an ADP receptor antagonized by ATP and expressed in platelets and megakaryoblastic cells. FEBS Lett. 1997; 403(1):26-30. [PubMed: 9038354]

[50]. Lambrecht G, Braun K, Damer M, Ganso M, Hildebrandt C, Ullmann H, Kassack MU, Nickel P. Structure-activity relationships of suramin and pyridoxal-5'-phosphate derivatives as $\mathrm{P} 2$ receptor antagonists. Curr. Pharm. Des. 2002; 8(26):2371-2399. [PubMed: 12369951]

[51]. Boyer JL, Romero-Avila T, Schachter JB, Harden TK. Identification of competitive antagonists of the P2Y1 receptor. Mol. Pharmacol. 1996; 50(5):1323-1329. [PubMed: 8913364]

[52]. Hechler B, Eckly A, Ohlmann P, Cazenave JP, Gachet C. The P2Y1 receptor, necessary but not sufficient to support full ADP-induced platelet aggregation, is not the target of the drug clopidogrel. Br. J. Haematol. 1998; 103(3):858-866. [PubMed: 9858246]

[53]. Boyer JL, Mohanram A, Camaioni E, Jacobson KA, Harden TK. Competitive and selective antagonism of P2Y1 receptors by N6-methyl 2'-deoxyadenosine 3',5'-bisphosphate. Br. J. Pharmacol. 1998; 124(1):1-3. [PubMed: 9630335]

[54]. Baurand A, Raboisson P, Freund M, Léon C, Cazenave JP, Bourguignon JJ, Gachet C. Inhibition of platelet function by administration of MRS2179, a P2Y1 receptor antagonist. Eur. J. Pharmacol. 2001; 412(3):213-221. [PubMed: 11166284]

[55]. Kim HS, Ohno M, Xu B, Kim HO, Choi Y, Ji XD, Maddileti S, Marquez VE, Harden TK, Jacobson KA. 2-Substitution of adenine nucleotide analogues containing a bicyclo[3.1.0]hexane ring system locked in a northern conformation: enhanced potency as P2Y1 receptor antagonists. J. Med. Chem. 2003; 46(23):4974-4987. [PubMed: 14584948]

[56]. Hechler B, Nonne C, Roh EJ, Cattaneo M, Cazenave JP, Lanza F, Jacobson KA, Gachet C. MRS2500 [2-iodo-N6-methyl-(N)-methanocarba-2'-deoxyadenosine-3',5'-bisphosphate], a 
potent, selective, and stable antagonist of the platelet $\mathrm{P} 2 \mathrm{Y} 1$ receptor with strong antithrombotic activity in mice. J. Pharmacol. Exp. Ther. 2006; 316(2):556-563. [PubMed: 16236815]

[57]. Boyer JL, Adams M, Ravi RG, Jacobson KA, Harden TK. 2-Chloro N(6)-methyl-(N)methanocarba-2'-deoxyadenosine-3',5'-bisphosphate is a selective high affinity $\mathrm{P}_{2} \mathrm{Y}_{1}$ receptor antagonist. Br. J. Pharmacol. 2002; 135(8):2004-2010. [PubMed: 11959804]

[58]. Camaioni E, Boyer JL, Mohanram A, Harden TK, Jacobson KA. Deoxyadenosine bisphosphate derivatives as potent antagonists at $\mathrm{P}_{2} \mathrm{Y}_{1}$ receptors. J. Med. Chem. 1998; 41(2):183-190. [PubMed: 9457242]

[59]. Simon J, Webb TE, Barnard EA. Distribution of $\left[{ }^{35}\right.$ S]dATP alpha S binding sites in the adult rat neuraxis. Neuropharmacology. 1997; 36(9):1243-1251. [PubMed: 9364479]

[60]. Moore D, Chambers J, Waldvogel H, Faull R, Emson P. Regional and cellular distribution of the $\mathrm{P}_{2} \mathrm{Y}_{1}$ purinergic receptor in the human brain: striking neuronal localisation. J. Comp. Neurol. 2000; 421(3):374-384. [PubMed: 10813793]

[61]. Morán-Jiménez MJ, Matute C. Immunohistochemical localization of the $\mathrm{P} 2 \mathrm{Y}_{1}$ purinergic receptor in neurons and glial cells of the central nervous system. Brain Res. Mol. Brain Res. 2000; 78(1-2):50-58. [PubMed: 10891584]

[62]. Fujita T, Tozaki-Saitoh H, Inoue K. P2Y1 receptor signaling enhances neuroprotection by astrocytes against oxidative stress via IL-6 release in hippocampal cultures. Glia. 2009; 57(3): 244-257. [PubMed: 18756525]

[63]. Mishra SK, Braun N, Shukla V, Füllgrabe M, Schomerus C, Korf HW, Gachet C, Ikehara Y, Sévigny J, Robson SC, Zimmermann H. Extracellular nucleotide signaling in adult neural stem cells: synergism with growth factor-mediated cellular proliferation. Development. 2006; 133(4): 675-684. [PubMed: 16436623]

[64]. Gerevich Z, Müller C, Illes P. Metabotropic P2Y1 receptors inhibit P2X3 receptor-channels in rat dorsal root ganglion neurons. Eur. J. Pharmacol. 2005; 521(1-3):34-38. [PubMed: 16181623]

[65]. Ruan HZ, Burnstock G. Localisation of P2Y1 and P2Y4 receptors in dorsal root, nodose and trigeminal ganglia of the rat. Histochem. Cell Biol. 2003; 120(5):415-426. [PubMed: 14564529]

[66]. Bianco F, Fumagalli M, Pravettoni E, D'Ambrosi N, Volonte C, Matteoli M, Abbracchio MP, Verderio C. Pathophysiological roles of extracellular nucleotides in glial cells: differential expression of purinergic receptors in resting and activated microglia. Brain Res. Brain Res. Rev. 2005; 48(2):144-156. [PubMed: 15850653]

[67]. Sanada M, Yasuda H, Omatsu-Kanbe M, Sango K, Isono T, Matsuura H, Kikkawa R. Increase in intracellular $\mathrm{Ca}^{2+}$ and calcitonin gene-related peptide release through metabotropic P2Y receptors in rat dorsal root ganglion neurons. Neuroscience. 2002; 111(2):413-422. [PubMed: 11983326]

[68]. Kobayashi K, Fukuoka T, Yamanaka H, Iyamanaka H, Dai Y, Obata K, Tokunaga A, Noguchi K. Neurons and glial cells differentially express P2Y receptor mRNAs in the rat dorsal root ganglion and spinal cord. J. Comp. Neurol. 2006; 498(4):443-454. [PubMed: 16874807]

[69]. Gallego D, Gil V, Martinez-Cutillas M, Mañe N, Martin MT, Jimenez M. Purinergic neuromuscular transmission is absent in the colon of P2Y1 knocked out mice. J. Physiol. 2012

[70]. Moore D, Iritani S, Chambers J, Emson P. Immunohistochemical localization of the P2Y1 purinergic receptor in Alzheimer's disease. Neuroreport. 2000; 11(17):3799-3803. [PubMed: 11117494]

[71]. Soulet C, Hechler B, Gratacap MP, Plantavid M, Offermanns S, Gachet C, Payrastre B. A differential role of the platelet ADP receptors P2Y1 and P2Y12 in Rac activation. J. Thromb. Haemost. 2005; 3(10):2296-2306. [PubMed: 16194206]

[72]. del Puerto A, Díaz-Hernández JI, Tapia M, Gomez-Villafuertes R, Benitez MJ, Zhang J, MirasPortugal MT, Wandosell F, Díaz-Hernández M, Garrido JJ. Adenylate cyclase 5 coordinates the action of ADP, P2Y1, P2Y13 and ATP-gated P2X7 receptors on axonal elongation. J. Cell Sci. 2012; 125:176-188. Pt 1. [PubMed: 22250198]

[73]. Tominaga M, Wada M, Masu M. Potentiation of capsaicin receptor activity by metabotropic ATP receptors as a possible mechanism for ATP-evoked pain and hyperalgesia. Proc. Natl. Acad. Sci. USA. 2001; 98(12):6951-6956. [PubMed: 11371611] 
[74]. Chen J, Wang L, Zhang Y, Yang J. P2Y1 purinoceptor inhibition reduces extracellular signalregulated protein kinase $1 / 2$ phosphorylation in spinal cord and dorsal root ganglia: implications for cancer-induced bone pain. Acta Biochim. Biophys. Sin(Shanghai). 2012; 44(4):367-372. [PubMed: 22349022]

[75]. Kittner H, Franke H, Fischer W, Schultheis N, Krügel U, Illes P. Stimulation of P2Y1 receptors causes anxiolytic-like effects in the rat elevated plus-maze: implications for the involvement of P2Y1 receptor-mediated nitric oxide production. Neuropsychopharmacology. 2003; 28(3):435444. [PubMed: 12629523]

[76]. Lustig KD, Sportiello MG, Erb L, Weisman GA. A nucleotide receptor in vascular endothelial cells is specifically activated by the fully ionized forms of ATP and UTP. Biochem. J. 1992; 284:733-739. Pt. 3. [PubMed: 1320376]

[77]. Parr CE, Sullivan DM, Paradiso AM, Lazarowski ER, Burch LH, Olsen JC, Erb L, Weisman GA, Boucher RC, Turner JT. Cloning and expression of a human $\mathrm{P}_{2} \mathrm{U}$ nucleotide receptor, a target for cystic fibrosis pharmacotherapy. Proc. Natl. Acad. Sci. USA. 1994; 91(8):3275-3279. [PubMed: 8159738]

[78]. Lazarowski ER, Watt WC, Stutts MJ, Brown HA, Boucher RC, Harden TK. Enzymatic synthesis of UTP gamma $\mathrm{S}$, a potent hydrolysis resistant agonist of $\mathrm{P}_{2 \mathrm{U}}$-purinoceptors. Br. J. Pharmacol. 1996; 117(1):203-209. [PubMed: 8825364]

[79]. Weisman GA, Wang M, Kong Q, Chorna NE, Neary JT, Sun GY, Gonzalez FA, Seye CI, Erb L. Molecular determinants of $\mathrm{P}_{2} \mathrm{Y}_{2}$ nucleotide receptor function: implications for proliferative and inflammatory pathways in astrocytes. Mol. Neurobiol. 2005; 31(1-3):169-183. [PubMed: 15953819]

[80]. Lazarowski ER, Watt WC, Stutts MJ, Boucher RC, Harden TK. Pharmacological selectivity of the cloned human $\mathrm{P}_{2 \mathrm{U}}$-purinoceptor: potent activation by diadenosine tetraphosphate. Br. J. Pharmacol. 1995; 116(1):1619-1627. [PubMed: 8564228]

[81]. Pendergast W, Yerxa BR, Douglass JG, Shaver SR, Dougherty RW, Redick CC, Sims IF, Rideout JL. Synthesis and P2Y receptor activity of a series of uridine dinucleoside 5'polyphosphates. Bioorg. Med. Chem. Lett. 2001; 11(2):157-160. [PubMed: 11206448]

[82]. Rieg T, Gerasimova M, Boyer JL, Insel PA, Vallon V. P2Y 2 receptor activation decreases blood pressure and increases renal $\mathrm{Na}^{+}$excretion. Am. J. Physiol. Regul. Integr. Comp. Physiol. 2011; 301(2):R510-R518. [PubMed: 21613580]

[83]. Yerxa BR, Sabater JR, Davis CW, Stutts MJ, Lang-Furr M, Picher M, Jones AC, Cowlen M, Dougherty R, Boyer J, Abraham WM, Boucher RC. Pharmacology of INS37217 [P(1)-(uridine 5')-P(4)-(2'-deoxycytidine 5')tetraphosphate, tetrasodium salt], a next-generation $\mathrm{P}_{2} \mathrm{Y}_{2}$ receptor agonist for the treatment of cystic fibrosis. J. Pharmacol. Exp. Ther. 2002; 302(3):871-880. [PubMed: 12183642]

[84]. Kellerman D, Evans R, Mathews D, Shaffer C. Inhaled P2Y2 receptor agonists as a treatment for patients with Cystic Fibrosis lung disease. Adv. Drug Deliv. Rev. 2002; 54(11):1463-1474. [PubMed: 12458155]

[85]. Mundasad MV, Novack GD, Allgood VE, Evans RM, Gorden JC, Yerxa BR. Ocular safety of INS365 ophthalmic solution: a P2Y 2 agonist in healthy subjects. J. Ocul. Pharmacol. Ther. 2001; 17(2):173-179. [PubMed: 11324984]

[86]. Tauber J, Davitt WF, Bokosky JE, Nichols KK, Yerxa BR, Schaberg AE, LaVange LM, MillsWilson MC, Kellerman DJ. Double-masked, placebo-controlled safety and efficacy trial of diquafosol tetrasodium(INS365) ophthalmic solution for the treatment of dry eye. Cornea. 2004; 23(8):784-792. [PubMed: 15502479]

[87]. Deterding RR, Lavange LM, Engels JM, Mathews DW, Coquillette SJ, Brody AS, Millard SP, Ramsey BW. Phase 2 randomized safety and efficacy trial of nebulized denufosol tetrasodium in cystic fibrosis. Am. J. Respir. Crit. Care Med. 2007; 176(4):362-369. [PubMed: 17446337]

[88]. Accurso FJ, Moss RB, Wilmott RW, Anbar RD, Schaberg AE, Durham TA, Ramsey BW. Denufosol tetrasodium in patients with cystic fibrosis and normal to mildly impaired lung function. Am. J. Respir. Crit. Care Med. 2011; 183(5):627-634. [PubMed: 21169471]

[89]. Jacobson KA, Costanzi S, Ivanov AA, Tchilibon S, Besada P, Gao ZG, Maddileti S, Harden TK. Structure activity and molecular modeling analyses of ribose- and base-modified uridine 5'- 
triphosphate analogues at the human P2Y2 and P2Y4 receptors. Biochem. Pharmacol. 2006; 71(4):540-549. [PubMed: 16359641]

[90]. El-Tayeb A, Qi A, Muller CE. Synthesis and structure-activity relationships of uracil nucleotide derivatives and analogues as agonists at human P2Y2, P2Y4, and P2Y6 receptors. J. Med. Chem. 2006; 49(24):7076-7087. [PubMed: 17125260]

[91]. Ko H, Carter RL, Cosyn L, Petrelli R, de Castro S, Besada P, Zhou Y, Cappellacci L, Franchetti P, Grifantini M, Van Calenbergh S, Harden TK, Jacobson KA. Synthesis and potency of novel uracil nucleotides and derivatives as P2Y2 and P2Y6 receptor agonists. Bioorg. Med. Chem. 2008; 16(12):6319-6332. [PubMed: 18514530]

[92]. El-Tayeb A, Qi A, Nicholas RA, Müller CE. Structural modifications of UMP, UDP, and UTP leading to subtype-selective agonists for P2Y2, P2Y4, and P2Y6 receptors. J. Med. Chem. 2011; 54(8):2878-2890. [PubMed: 21417463]

[93]. Bagchi S, Liao Z, Gonzalez FA, Chorna NE, Seye CI, Weisman GA, Erb L. The P2Y 2 nucleotide receptor interacts with $a_{V}$ integrins to activate $G_{0}$ and induce cell migration. J. Biol. Chem. 2005; 280(47):39050-39057. [PubMed: 16186116]

[94]. Liao Z, Seye CI, Weisman GA, Erb L. The P2 $\mathrm{Y}_{2}$ nucleotide receptor requires interaction with $\mathrm{a}_{\mathrm{V}}$ integrins to access and activate $\mathrm{G}_{12}$. J. Cell Sci. 2007; 120:1654-1662. Pt 9. [PubMed: 17452627]

[95]. Erb L, Liu J, Ockerhausen J, Kong Q, Garrad RC, Griffin K, Neal C, Krugh B, Santiago-Pérez LI, González FA, Gresham HD, Turner JT, Weisman GA. An RGD sequence in the P2Y 2 receptor interacts with $\alpha_{V} \beta_{3}$ integrins and is required for $G_{0}$-mediated signal transduction. J. Cell Biol. 2001; 153(3):491-501. [PubMed: 11331301]

[96]. Murthy KS, Makhlouf GM. Coexpression of ligand-gated P2X and G protein-coupled P2Y receptors in smooth muscle. Preferential activation of $\mathrm{P} 2 \mathrm{Y}$ receptors coupled to phospholipase C(PLC)-beta1 via Galphaq/11 and to PLC-beta3 via Gbetagammai3. J. Biol. Chem. 1998; 273(8):4695-4704. [PubMed: 9468531]

[97]. Baltensperger K, Porzig H. The P2U purinoceptor obligatorily engages the heterotrimeric G protein G16 to mobilize intracellular Ca2+ in human erythroleukemia cells. J. Biol. Chem. 1997; 272(15):10151-10159. [PubMed: 9092561]

[98]. Gallagher CJ, Salter MW. Differential properties of astrocyte calcium waves mediated by P2Y1 and P2Y2 receptors. J. Neurosci. 2003; 23(17):6728-6739. [PubMed: 12890765]

[99]. Charlton SJ, Brown CA, Weisman GA, Turner JT, Erb L, Boarder MR. PPADS and suramin as antagonists at cloned $\mathrm{P}_{2 \mathrm{Y}^{-}}$and $\mathrm{P}_{2 \mathrm{U}}$-purinoceptors. Br. J. Pharmacol. 1996; 118(3):704-710. [PubMed: 8762097]

[100]. Weyler S, Baqi Y, Hillmann P, Kaulich M, Hunder AM, Müller IA, Müller CE. Combinatorial synthesis of anilinoanthraquinone derivatives and evaluation as non-nucleotide-derived P2Y2 receptor antagonists. Bioorg. Med. Chem. Lett. 2008; 18(1):223-227. [PubMed: 18006312]

[101]. Yu N, Erb L, Shivaji R, Weisman GA, Seye CI. Binding of the P2 $Y_{2}$ nucleotide receptor to filamin A regulates migration of vascular smooth muscle cells. Circ. Res. 2008; 102(5):581-588. [PubMed: 18202316]

[102]. Arthur DB, Georgi S, Akassoglou K, Insel PA. Inhibition of apoptosis by P2Y2 receptor activation: novel pathways for neuronal survival. J. Neurosci. 2006; 26(14):3798-3804. [PubMed: 16597733]

[103]. Franke H, Illes P. Involvement of P2 receptors in the growth and survival of neurons in the CNS. Pharmacol. Ther. 2006; 109(3):297-324. [PubMed: 16102837]

[104]. Inoue K. Purinergic systems in microglia. Cell Mol. Life Sci. 2008; 65(19):3074-3080. [PubMed: 18563292]

[105]. Peterson TS, Camden JM, Wang Y, Seye CI, Wood WG, Sun GY, Erb L, Petris MJ, Weisman GA. P2 $Y_{2}$ nucleotide receptor-mediated responses in brain cells. Mol. Neurobiol. 2010; 41(2-3): 356-366. [PubMed: 20387013]

[106]. Chen Y, Yao Y, Sumi Y, Li A, To UK, Elkhal A, Inoue Y, Woehrle T, Zhang Q, Hauser C, Junger WG. Purinergic signaling: a fundamental mechanism in neutrophil activation. Sci. Signal. 2010; 3(125):ra45. [PubMed: 20530802] 
[107]. Schrader AM, Camden JM, Weisman GA. P2Y 2 nucleotide receptor up-regulation in submandibular gland cells from the NOD B10 mouse model of Sjogren's syndrome. Arch. Oral Biol. 2005; 50(6):533-540. [PubMed: 15848146]

[108]. Koshiba M, Apasov S, Sverdlov V, Chen P, Erb L, Turner JT, Weisman GA, Sitkovsky MV. Transient up-regulation of $\mathrm{P}_{2} \mathrm{Y}_{2}$ nucleotide receptor mRNA expression is an immediate early gene response in activated thymocytes. Proc. Natl. Acad. Sci. USA. 1997; 94(3):831-836. [PubMed: 9023342]

[109]. Seye CI, Kong Q, Erb L, Garrad RC, Krugh B, Wang M, Turner JT, Sturek M, Gonzalez FA, Weisman GA. Functional P2Y 2 nucleotide receptors mediate uridine 5'-triphosphate-induced intimal hyperplasia in collared rabbit carotid arteries. Circulation. 2002; 106(21):2720-2726. [PubMed: 12438299]

[110]. Shen J, Seye CI, Wang M, Weisman GA, Wilden PA, Sturek M. Cloning, up-regulation, and mitogenic role of porcine $\mathrm{P}_{2} \mathrm{Y}_{2}$ receptor in coronary artery smooth muscle cells. Mol. Pharmacol. 2004; 66(5):1265-1274. [PubMed: 15280443]

[111]. Turner JT, Weisman GA, Camden JM. Upregulation of $\mathrm{P}_{2} \mathrm{Y}_{2}$ nucleotide receptors in rat salivary gland cells during short-term culture. Am. J. Physiol. 1997; 273(3):C1100-C1107. Pt 1. [PubMed: 9316432]

[112]. Rodríguez-Zayas AE, Torrado AI, Miranda JD. P2Y2 receptor expression is altered in rats after spinal cord injury. Int. J. Dev. Neurosci. 2010; 28(6):413-421. [PubMed: 20619335]

[113]. Franke H, Krugel U, Grosche J, Heine C, Hartig W, Allgaier C, Illes P. P2Y receptor expression on astrocytes in the nucleus accumbens of rats. Neuroscience. 2004; 127(2):431-441. [PubMed: 15262333]

[114]. Lee YJ, Han SB, Nam SY, Oh KW, Hong JT. Inflammation and Alzheimer's disease. Arch. Pharm. Res. 2010; 33(10):1539-1556. [PubMed: 21052932]

[115]. Cacabelos R, Alvarez XA, Fernandez-Novoa L, Franco A, Mangues R, Pellicer A, Nishimura T. Brain interleukin-1 beta in Alzheimer's disease and vascular dementia. Methods Find. Exp. Clin. Pharmacol. 1994; 16(2):141-151. [PubMed: 8007743]

[116]. Degagne E, Grbic DM, Dupuis AA, Lavoie EG, Langlois C, Jain N, Weisman GA, Sevigny J, Gendron FP. P2 $Y_{2}$ receptor transcription is increased by NF-kappa B and stimulates cyclooxygenase-2 expression and PGE2 released by intestinal epithelial cells. J. Immunol. 2009; 183(7):4521-4529. [PubMed: 19734210]

[117]. Wullaert A, Bonnet MC, Pasparakis M. NF-kappaB in the regulation of epithelial homeostasis and inflammation. Cell Res. 2011; 21(1):146-158. [PubMed: 21151201]

[118]. Honda S, Sasaki Y, Ohsawa K, Imai Y, Nakamura Y, Inoue K, Kohsaka S. Extracellular ATP or ADP induce chemotaxis of cultured microglia through Gi/o-coupled P2Y receptors. J. Neurosci. 2001; 21(6):1975-1982. [PubMed: 11245682]

[119]. Wang M, Kong Q, Gonzalez FA, Sun G, Erb L, Seye C, Weisman GA. P2Y 2 nucleotide receptor interaction with $a_{\mathrm{V}}$ integrin mediates astrocyte migration. J. Neurochem. 2005; 95(3): 630-640. [PubMed: 16135088]

[120]. Washburn KB, Neary JT. P2 purinergic receptors signal to STAT3 in astrocytes: Difference in STAT3 responses to P2Y and P2X receptor activation. Neuroscience. 2006; 142(2):411-423. [PubMed: 16905269]

[121]. Xu J, Wang F, Van Keymeulen A, Herzmark P, Straight A, Kelly K, Takuwa Y, Sugimoto N, Mitchison T, Bourne HR. Divergent signals and cytoskeletal assemblies regulate self-organizing polarity in neutrophils. Cell. 2003; 114(2):201-214. [PubMed: 12887922]

[122]. Ridley AJ. Rho GTPases and cell migration. J. Cell Sci. 2001; 114:2713-2722. Pt 15. [PubMed: 11683406]

[123]. Soltoff SP, Avraham H, Avraham S, Cantley LC. Activation of P2 $Y_{2}$ receptors by UTP and ATP stimulates mitogen-activated kinase activity through a pathway that involves related adhesion focal tyrosine kinase and protein kinase C. J. Biol. Chem. 1998; 273(5):2653-2660. [PubMed: 9446569]

[124]. Soltoff SP. Related adhesion focal tyrosine kinase and the epidermal growth factor receptor mediate the stimulation of mitogen-activated protein kinase by the G-protein-coupled $\mathrm{P}_{2} \mathrm{Y}_{2}$ 
receptor. Phorbol ester or $\left[\mathrm{Ca}^{2+}\right]_{\mathrm{i}}$ elevation can substitute for receptor activation. J. Biol. Chem. 1998; 273(36):23110-23117. [PubMed: 9722539]

[125]. Seye CI, Yu N, Gonzalez FA, Erb L, Weisman GA. The P2Y 2 nucleotide receptor mediates vascular cell adhesion molecule-1 expression through interaction with VEGF receptor-2(KDR/ Flk-1). J. Biol. Chem. 2004; 279(34):35679-35686. [PubMed: 15175347]

[126]. Liu J, Liao Z, Camden J, Griffin KD, Garrad RC, Santiago-Perez LI, Gonzalez FA, Seye CI, Weisman GA, Erb L. Src homology 3 binding sites in the $\mathrm{P}_{2} \mathrm{Y}_{2}$ nucleotide receptor interact with $\mathrm{Src}$ and regulate activities of Src, proline-rich tyrosine kinase 2, and growth factor receptors. J. Biol. Chem. 2004; 279(9):8212-8218. [PubMed: 14670955]

[127]. Garrad RC, Otero MA, Erb L, Theiss PM, Clarke LL, Gonzalez FA, Turner JT, Weisman GA. Structural basis of agonist-induced desensitization and sequestration of the $\mathrm{P}_{2} \mathrm{Y}_{2}$ nucleotide receptor. Consequences of truncation of the C terminus. J. Biol. Chem. 1998; 273(45):2943729444. [PubMed: 9792648]

[128]. Norambuena A, Palma F, Poblete MI, Donoso MV, Pardo E, González A, Huidobro-Toro JP. UTP controls cell surface distribution and vasomotor activity of the human P2Y2 receptor through an epidermal growth factor receptor-transregulated mechanism. J. Biol. Chem. 2010; 285(5):2940-2950. [PubMed: 19996104]

[129]. Pooler AM, Guez DH, Benedictus R, Wurtman RJ. Uridine enhances neurite outgrowth in nerve growth factor-differentiated PC12 [corrected]. Neuroscience. 2005; 134(1):207-214. [PubMed: 15939540]

[130]. Camden JM, Schrader AM, Camden RE, Gonzalez FA, Erb L, Seye CI, Weisman GA. P2Y 2 nucleotide receptors enhance a-secretase-dependent amyloid precursor protein processing. J. Biol. Chem. 2005; 280(19):18696-18702. [PubMed: 15778502]

[131]. Boucsein C, Zacharias R, Färber K, Pavlovic S, Hanisch UK, Kettenmann H. Purinergic receptors on microglial cells: functional expression in acute brain slices and modulation of microglial activation in vitro. Eur. J. Neurosci. 2003; 17(11):2267-2276. [PubMed: 12814360]

[132]. Lai MK, Tan MG, Kirvell S, Hobbs C, Lee J, Esiri MM, Chen CP, Francis PT. Selective loss of P2Y2 nucleotide receptor immunoreactivity is associated with Alzheimer's disease neuropathology. J. Neural Transm. 2008; 115(8):1165-1172. [PubMed: 18506388]

[133]. Halassa MM, Fellin T, Haydon PG. Tripartite synapses: roles for astrocytic purines in the control of synaptic physiology and behavior. Neuropharmacology. 2009; 57(4):343-346. [PubMed: 19577581]

[134]. Chorna NE, Santiago-Perez LI, Erb L, Seye CI, Neary JT, Sun GY, Weisman GA, Gonzalez FA. P2Y receptors activate neuroprotective mechanisms in astrocytic cells. J. Neurochem. 2004; 91(1):119-132. [PubMed: 15379893]

[135]. Chen X, Molliver DC, Gebhart GF. The P2Y2 receptor sensitizes mouse bladder sensory neurons and facilitates purinergic currents. J. Neurosci. 2010; 30(6):2365-2372. [PubMed: 20147562]

[136]. Wang H, Wang DH, Galligan JJ. P2Y2 receptors mediate ATP-induced resensitization of TRPV1 expressed by kidney projecting sensory neurons. Am. J. Physiol. Regul. Integr. Comp. Physiol. 2010; 298(6):R1634-R1641. [PubMed: 20335377]

[137]. Culpan D, MacGowan SH, Ford JM, Nicoll JA, Griffin WS, Dewar D, Cairns NJ, Hughes A, Kehoe PG, Wilcock GK. Tumour necrosis factor-alpha gene polymorphisms and Alzheimer's disease. Neurosci. Lett. 2003; 350(1):61-65. [PubMed: 12962917]

[138]. Tarkowski E, Liljeroth AM, Minthon L, Tarkowski A, Wallin A, Blennow K. Cerebral pattern of pro- and anti-inflammatory cytokines in dementias. Brain Res. Bull. 2003; 61(3):255-260. [PubMed: 12909295]

[139]. Zhong Z, Deane R, Ali Z, Parisi M, Shapovalov Y, O'Banion MK, Stojanovic K, Sagare A, Boillee S, Cleveland DW, Zlokovic BV. ALS-causing SOD1 mutants generate vascular changes prior to motor neuron degeneration. Nat. Neurosci. 2008; 11(4):420-422. [PubMed: 18344992]

[140]. Bell RD, Winkler EA, Sagare AP, Singh I, LaRue B, Deane R, Zlokovic BV. Pericytes control key neurovascular functions and neuronal phenotype in the adult brain and during brain aging. Neuron. 2010; 68(3):409-427. [PubMed: 21040844] 
[141]. Zlokovic BV. The blood-brain barrier in health and chronic neurodegenerative disorders. Neuron. 2008; 57(2):178-201. [PubMed: 18215617]

[142]. Winkler EA, Bell RD, Zlokovic BV. Central nervous system pericytes in health and disease. Nat. Neurosci. 2011; 14(11):1398-1405. [PubMed: 22030551]

[143]. Terada H, Kajiura T, Kyoi K, Utsumi S, Hori H. Effects of ATP on cerebral circulation-morphological observation of cerebral circulation and cerebral vasculature. No. To. Shinkei. 1976; 28(2):151-156. [PubMed: 1036039]

[144]. Miyagi Y, Kobayashi S, Nishimura J, Fukui M, Kanaide H. Dual regulation of cerebrovascular tone by UTP: P2U receptor-mediated contraction and endothelium-dependent relaxation. Br. J. Pharmacol. 1996; 118(4):847-856. [PubMed: 8799553]

[145]. Guns PJ, Van Assche T, Fransen P, Robaye B, Boeynaems JM, Bult H. Endothelium-dependent relaxation evoked by ATP and UTP in the aorta of P2Y2-deficient mice. Br. J. Pharmacol. 2006; 147(5):569-574. [PubMed: 16415908]

[146]. Kennedy C, Burnstock G. ATP produces vasodilation via $\mathrm{P} 1$ purinoceptors and vasoconstriction via $\mathrm{P} 2$ purinoceptors in the isolated rabbit central ear artery. Blood Vessels. 1985; 22(3):145155. [PubMed: 2988672]

[147]. Ralevic V, Burnstock G. Relative contribution of P2U- and P2Y-purinoceptors to endotheliumdependent vasodilatation in the golden hamster isolated mesenteric arterial bed. Br. J. Pharmacol. 1996; 117(8):1797-1802. [PubMed: 8732294]

[148]. Ralevic V, Burnstock G. Discrimination by PPADS between endothelial P2Y- and P2Upurinoceptors in the rat isolated mesenteric arterial bed. Br. J. Pharmacol. 1996; 118(2):428-434. [PubMed: 8735648]

[149]. Olesen SP, Crone C. Substances that rapidly augment ionic conductance of endothelium in cerebral venules. Acta Physiol. Scand. 1986; 127(2):233-241. [PubMed: 3487916]

[150]. Pocock TM, Williams B, Curry FE, Bates DO. VEGF and ATP act by different mechanisms to increase microvascular permeability and endothelial $\left[\mathrm{Ca}_{2+}\right]_{\mathrm{i}}$. Am. J. Physiol. Heart Circ. Physiol. 2000; 279(4):H1625-H1634. [PubMed: 11009449]

[151]. Guns PJ, Korda A, Crauwels HM, Van Assche T, Robaye B, Boeynaems JM, Bult H. Pharmacological characterization of nucleotide $\mathrm{P} 2 \mathrm{Y}$ receptors on endothelial cells of the mouse aorta. Br. J. Pharmacol. 2005; 146(2):288-295. [PubMed: 15997227]

[152]. Wihlborg AK, Malmsjo M, Eyjolfsson A, Gustafsson R, Jacobson K, Erlinge D. Extracellular nucleotides induce vasodilatation in human arteries via prostaglandins, nitric oxide and endothelium-derived hyperpolarising factor. Br. J. Pharmacol. 2003; 138(8):1451-1458. [PubMed: 12721100]

[153]. Kunapuli SP, Daniel JL. P2 receptor subtypes in the cardiovascular system. Biochem. J. 1998; 336:513-523. Pt. 3. [PubMed: 9841859]

[154]. Anderson CM, Nedergaard M. Astrocyte-mediated control of cerebral microcirculation. Trends Neurosci. 2003; 26(7):340-344. [PubMed: 12850427]

[155]. Simard M, Arcuino G, Takano T, Liu QS, Nedergaard M. Signaling at the gliovascular interface. J. Neurosci. 2003; 23(27):9254-9262. [PubMed: 14534260]

[156]. Lewis CJ, Ennion SJ, Evans RJ. P2 purinoceptor-mediated control of rat cerebral(pial) microvasculature; contribution of P2X and P2Y receptors. J. Physiol. 2000; 527:315-324. Pt. 2. [PubMed: 10970432]

[157]. Webb TE, Henderson DJ, Roberts JA, Barnard EA. Molecular cloning and characterization of the rat P2Y4 receptor. J. Neurochem. 1998; 71(4):1348-1357. [PubMed: 9751165]

[158]. Brunschweiger A, Muller CE. P2 receptors activated by uracil nucleotides--an update. Curr. Med. Chem. 2006; 13(3):289-312. [PubMed: 16475938]

[159]. Jacobson KA, Ivanov AA, de Castro S, Harden TK, Ko H. Development of selective agonists and antagonists of P2Y receptors. Purinergic Signal. 2009; 5(1):75-89. [PubMed: 18600475]

[160]. Communi D, Motte S, Boeynaems JM, Pirotton S. Pharmacological characterization of the human P2Y4 receptor. Eur. J. Pharmacol. 1996; 317(2-3):383-389. [PubMed: 8997625]

[161]. Luykenaar KD, El-Rahman RA, Walsh MP, Welsh DG. Rho-kinase-mediated suppression of KDR current in cerebral arteries requires an intact actin cytoskeleton. Am. J. Physiol. Heart Circ. Physiol. 2009; 296(4):H917-H926. [PubMed: 19218502] 
[162]. Herold CL, Qi AD, Harden TK, Nicholas RA. Agonist versus antagonist action of ATP at the P2Y4 receptor is determined by the second extracellular loop. J. Biol. Chem. 2004; 279(12): 11456-11464. [PubMed: 14670966]

[163]. Jacobson KA, Jarvis MF, Williams M. Purine and pyrimidine(P2) receptors as drug targets. J. Med. Chem. 2002; 45(19):4057-4093. [PubMed: 12213051]

[164]. Moore DJ, Chambers JK, Wahlin JP, Tan KB, Moore GB, Jenkins O, Emson PC, Murdock PR. Expression pattern of human $\mathrm{P} 2 \mathrm{Y}$ receptor subtypes: a quantitative reverse transcriptionpolymerase chain reaction study. Biochim. Biophys. Acta. 2001; 1521(1-3):107-119. [PubMed: 11690642]

[165]. Lenz G, Gottfried C, Luo Z, Avruch J, Rodnight R, Nie WJ, Kang Y, Neary JT. P 2 Y purinoceptor subtypes recruit different mek activators in astrocytes. Br. J. Pharmacol. 2000; 129(5):927-936. [PubMed: 10696092]

[166]. Zonta M, Angulo MC, Gobbo S, Rosengarten B, Hossmann KA, Pozzan T, Carmignoto G. Neuron-to-astrocyte signaling is central to the dynamic control of brain microcirculation. Nat. Neurosci. 2003; 6(1):43-50. [PubMed: 12469126]

[167]. Communi D, Parmentier M, Boeynaems JM. Cloning, functional expression and tissue distribution of the human P2Y6 receptor. Biochem. Biophys. Res. Commun. 1996; 222(2):303308. [PubMed: 8670200]

[168]. Besada P, Shin DH, Costanzi S, Ko H, Mathé C, Gagneron J, Gosselin G, Maddileti S, Harden TK, Jacobson KA. Structure-activity relationships of uridine 5'-diphosphate analogues at the human P2Y6 receptor. J. Med. Chem. 2006; 49(18):5532-5543. [PubMed: 16942026]

[169]. Mamedova LK, Wang R, Besada P, Liang BT, Jacobson KA. Attenuation of apoptosis in vitro and ischemia/reperfusion injury in vivo in mouse skeletal muscle by $\mathrm{P} 2 \mathrm{Y} 6$ receptor activation. Pharmacol. Res. 2008; 58(3-4):232-239. [PubMed: 18805489]

[170]. Schreiber R, Kunzelmann K. Purinergic P2Y6 receptors induce $\mathrm{Ca}^{2+}$ and $\mathrm{CFTR}^{2}$ dependent $\mathrm{Cl}^{-}$ secretion in mouse trachea. Cell. Physiol. Biochem. 2005; 16(1-3):99-108. [PubMed: 16121038]

[171]. Korcok J, Raimundo LN, Du X, Sims SM, Dixon SJ. P2Y6 nucleotide receptors activate NFkappaB and increase survival of osteoclasts. J. Biol. Chem. 2005; 280(17):16909-16915. [PubMed: 15722352]

[172]. Chang K, Hanaoka K, Kumada M, Takuwa Y. Molecular cloning and functional analysis of a novel P2 nucleotide receptor. J. Biol. Chem. 1995; 270(44):26152-26158. [PubMed: 7592819]

[173]. Filippov AK, Webb TE, Barnard EA, Brown DA. Dual coupling of heterologously-expressed rat P2Y6 nucleotide receptors to $\mathrm{N}$-type $\mathrm{Ca}^{2+}$ and $\mathrm{M}$-type $\mathrm{K}^{+}$currents in rat sympathetic neurones. Br. J. Pharmacol. 1999; 126(4):1009-1017. [PubMed: 10193782]

[174]. Nishida M, Sato Y, Uemura A, Narita Y, Tozaki-Saitoh H, Nakaya M, Ide T, Suzuki K, Inoue K, Nagao T, Kurose H. P2Y6 receptor-Galpha12/13 signalling in cardiomyocytes triggers pressure overload-induced cardiac fibrosis. EMBO J. 2008; 27(23):3104-3115. [PubMed: 19008857]

[175]. Mamedova LK, Joshi BV, Gao ZG, von Kügelgen I, Jacobson KA. Diisothiocyanate derivatives as potent, insurmountable antagonists of P2Y6 nucleotide receptors. Biochem. Pharmacol. 2004; 67(9):1763-1770. [PubMed: 15081875]

[176]. Robaye B, Boeynaems JM, Communi D. Slow desensitization of the human P2Y6 receptor. Eur. J. Pharmacol. 1997; 329(2-3):231-236. [PubMed: 9226417]

[177]. Calvert JA, Atterbury-Thomas AE, Leon C, Forsythe ID, Gachet C, Evans RJ. Evidence for P2Y1, P2Y2, P2Y6 and atypical UTP-sensitive receptors coupled to rises in intracellular calcium in mouse cultured superior cervical ganglion neurons and glia. Br. J. Pharmacol. 2004; 143(5): 525-532. [PubMed: 15466449]

[178]. Bennett GC, Ford AP, Smith JA, Emmett CJ, Webb TE, Boarder MR. P2Y receptor regulation of cultured rat cerebral cortical cells: calcium responses and mRNA expression in neurons and glia. Br. J. Pharmacol. 2003; 139(2):279-288. [PubMed: 12770933]

[179]. Koizumi S, Shigemoto-Mogami Y, Nasu-Tada K, Shinozaki Y, Ohsawa K, Tsuda M, Joshi BV, Jacobson KA, Kohsaka S, Inoue K. UDP acting at P2Y6 receptors is a mediator of microglial phagocytosis. Nature. 2007; 446(7139):1091-1095. [PubMed: 17410128] 
[180]. Liu GD, Ding JQ, Xiao Q, Chen SD. P2Y6 receptor and immunoinflammation. Neurosci. Bull. 2009; 25(3):161-164. [PubMed: 19448690]

[181]. D'Ambrosi N, Iafrate M, Saba E, Rosa P, Volonte C. Comparative analysis of P2Y4 and P2Y6 receptor architecture in native and transfected neuronal systems. Biochim. Biophys. Acta. 2007; 1768(6):1592-1599. [PubMed: 17481575]

[182]. Communi D, Robaye B, Boeynaems JM. Pharmacological characterization of the human P2Y11 receptor. Br. J. Pharmacol. 1999; 128(6):1199-1206. [PubMed: 10578132]

[183]. White PJ, Webb TE, Boarder MR. Characterization of a $\mathrm{Ca}^{2+}$ response to both UTP and ATP at human P2Y11 receptors: evidence for agonist-specific signaling. Mol. Pharmacol. 2003; 63(6): 1356-1363. [PubMed: 12761346]

[184]. Ingall AH, Dixon J, Bailey A, Coombs ME, Cox D, McInally JI, Hunt SF, Kindon ND, Teobald BJ, Willis PA, Humphries RG, Leff P, Clegg JA, Smith JA, Tomlinson W. Antagonists of the platelet P2T receptor: a novel approach to antithrombotic therapy. J. Med. Chem. 1999; 42(2): 213-220. [PubMed: 9925726]

[185]. Meis S, Hamacher A, Hongwiset D, Marzian C, Wiese M, Eckstein N, Royer HD, Communi D, Boeynaems JM, Hausmann R, Schmalzing G.; Kassack, M.U. NF546 [4,4'(carbonylbis(imino-3,1-phenylene-carbonylimino-3,1-(4-methyl-phenylene)-carbonylimino))bis(1,3-xylene-alpha,alpha'-diphosphonic acid) tetrasodium salt] is a non-nucleotide P2Y11 agonist and stimulates release of interleukin-8 from human monocyte-derived dendritic cells. J. Pharmacol. Exp. Ther. 2010; 332(1):238-247. [PubMed: 19815812]

[186]. Moreschi I, Bruzzone S, Bodrato N, Usai C, Guida L, Nicholas RA, Kassack MU, Zocchi E, De Flora A. NAADP+ is an agonist of the human P2Y11 purinergic receptor. Cell. Calcium. 2008; 43(4):344-355. [PubMed: 17707504]

[187]. Moreschi I, Bruzzone S, Nicholas RA, Fruscione F, Sturla L, Benvenuto F, Usai C, Meis S, Kassack MU, Zocchi E, De Flora A. Extracellular NAD+ is an agonist of the human P2Y11 purinergic receptor in human granulocytes. J. Biol. Chem. 2006; 281(42):31419-31429. [PubMed: 16926152]

[188]. Nguyen TD, Meichle S, Kim US, Wong T, Moody MW. P2Y $\mathrm{Y}_{11}$, a purinergic receptor acting via cAMP, mediates secretion by pancreatic duct epithelial cells. Am. J. Physiol. Gastrointest. Liver Physiol. 2001; 280(5):G795-G804. [PubMed: 11292586]

[189]. Kaufmann A, Musset B, Limberg SH, Renigunta V, Sus R, Dalpke AH, Heeg KM, Robaye B, Hanley PJ. "Host tissue damage" signal ATP promotes non-directional migration and negatively regulates toll-like receptor signaling in human monocytes. J. Biol. Chem. 2005; 280(37):3245932467. [PubMed: 16030017]

[190]. Vaughan KR, Stokes L, Prince LR, Marriott HM, Meis S, Kassack MU, Bingle CD, Sabroe I, Surprenant A, Whyte MK. Inhibition of neutrophil apoptosis by ATP is mediated by the P2Y11 receptor. J. Immunol. 2007; 179(12):8544-8553. [PubMed: 18056402]

[191]. Ecke D, Hanck T, Tulapurkar ME, Schafer R, Kassack M, Stricker R, Reiser G. Heterooligomerization of the $\mathrm{P} 2 \mathrm{Y} 11$ receptor with the $\mathrm{P} 2 \mathrm{Y} 1$ receptor controls the internalization and ligand selectivity of the P2Y11 receptor. Biochem. J. 2008; 409(1):107-116. [PubMed: 17824841]

[192]. Swennen EL, Bast A, Dagnelie PC. Purinergic receptors involved in the immunomodulatory effects of ATP in human blood. Biochem. Biophys. Res. Commun. 2006; 348(3):1194-1199. [PubMed: 16904065]

[193]. Ullmann H, Meis S, Hongwiset D, Marzian C, Wiese M, Nickel P, Communi D, Boeynaems JM, Wolf C, Hausmann R, Schmalzing G, Kassack MU. Synthesis and structure-activity relationships of suramin-derived P2Y11 receptor antagonists with nanomolar potency. J. Med. Chem. 2005; 48(22):7040-7048. [PubMed: 16250663]

[194]. Volonté C, Amadio S, D'Ambrosi N, Colpi M, Burnstock G. P2 receptor web: complexity and fine-tuning. Pharmacol. Ther. 2006; 112(1):264-280. [PubMed: 16780954]

[195]. Zhang FL, Luo L, Gustafson E, Palmer K, Qiao X, Liu YH, Chen G, Pramanik B, Laz TM, Palmer K, Bayne M, Monsma FJ Jr. ADP is the cognate ligand for the orphan G protein-coupled receptor SP1999. J. Biol. Chem. 2001; 276(11):8608-8615. [PubMed: 11104774] 
[196]. Soulet C, Sauzeau V, Plantavid M, Herbert JM, Pacaud P, Payrastre B, Savi P. Gi-dependent and -independent mechanisms downstream of the P2Y12 ADP-receptor. J. Thromb. Haemost. 2004; 2(1):135-146. [PubMed: 14717977]

[197]. Van Kolen K, Slegers H. Atypical PKCzeta is involved in RhoA-dependent mitogenic signaling by the P2Y 12 receptor in C6 cells. FEBS J. 2006; 273(8):1843-1854. [PubMed: 16623718]

[198]. Ben Addi A, Cammarata D, Conley PB, Boeynaems JM, Robaye B. Role of the P2Y12 receptor in the modulation of murine dendritic cell function by ADP. J. Immunol. 2010; 185(10):59005906. [PubMed: 20952684]

[199]. Bodor ET, Waldo GL, Hooks SB, Corbitt J, Boyer JL, Harden TK. Purification and functional reconstitution of the human P2Y12 receptor. Mol. Pharmacol. 2003; 64(5):1210-1216. [PubMed: 14573771]

[200]. Jantzen HM, Gousset L, Bhaskar V, Vincent D, Tai A, Reynolds EE, Conley PB. Evidence for two distinct G-protein-coupled ADP receptors mediating platelet activation. Thromb. Haemost. 1999; 81(1):111-117. [PubMed: 10348701]

[201]. Xu B, Stephens A, Kirschenheuter G, Greslin AF, Cheng X, Sennelo J, Cattaneo M, Zighetti ML, Chen A, Kim SA, Kim HS, Bischofberger N, Cook G, Jacobson KA. Acyclic analogues of adenosine bisphosphates as P2Y receptor antagonists: phosphate substitution leads to multiple pathways of inhibition of platelet aggregation. J. Med. Chem. 2002; 45(26):5694-5709. [PubMed: 12477353]

[202]. Dorsam RT, Kunapuli SP. Central role of the P2Y12 receptor in platelet activation. J. Clin. Invest. 2004; 113(3):340-345. [PubMed: 14755328]

[203]. Wallentin L. P2Y 12 inhibitors: differences in properties and mechanisms of action and potential consequences for clinical use. Eur. Heart J. 2009; 30(16):1964-1977. [PubMed: 19633016]

[204]. Savi P, Herbert JM. Clopidogrel and ticlopidine: P2Y12 adenosine diphosphate-receptor antagonists for the prevention of atherothrombosis. Semin. Thromb. Hemost. 2005; 31(2):174183. [PubMed: 15852221]

[205]. Niitsu Y, Jakubowski JA, Sugidachi A, Asai F. Pharmacology of CS-747(prasugrel, LY640315), a novel, potent antiplatelet agent with in vivo P2Y12 receptor antagonist activity. Semin. Thromb. Hemost. 2005; 31(2):184-194. [PubMed: 15852222]

[206]. Thebault JJ, Blatrix CE, Blanchard JF, Panak EA. Effects of ticlopidine, a new platelet aggregation inhibitor in man. Clin. Pharmacol. Ther. 1975; 18(4):485-490. [PubMed: 1100310]

[207]. Hollopeter G, Jantzen HM, Vincent D, Li G, England L, Ramakrishnan V, Yang RB, Nurden P, Nurden A, Julius D, Conley PB. Identification of the platelet ADP receptor targeted by antithrombotic drugs. Nature. 2001; 409(6817):202-207. [PubMed: 11196645]

[208]. Savi P, Zachayus JL, Delesque-Touchard N, Labouret C, Hervé C, Uzabiaga MF, Pereillo JM, Culouscou JM, Bono F, Ferrara P, Herbert JM. The active metabolite of Clopidogrel disrupts P2Y12 receptor oligomers and partitions them out of lipid rafts. Proc. Natl. Acad. Sci. USA. 2006; 103(29):11069-11074. [PubMed: 16835302]

[209]. Gachet C. ADP receptors of platelets and their inhibition. Thromb. Haemost. 2001; 86(1):222232. [PubMed: 11487010]

[210]. Gachet C. The platelet P2 receptors as molecular targets for old and new antiplatelet drugs. Pharmacol. Ther. 2005; 108(2):180-192. [PubMed: 15955565]

[211]. van Giezen JJ, Humphries RG. Preclinical and clinical studies with selective reversible direct P2Y12 antagonists. Semin. Thromb. Hemost. 2005; 31(2):195-204. [PubMed: 15852223]

[212]. Cannon CP, Husted S, Harrington RA, Scirica BM, Emanuelsson H, Peters G, Storey RF. Safety, tolerability, and initial efficacy of AZD6140, the first reversible oral adenosine diphosphate receptor antagonist, compared with clopidogrel, in patients with non-ST-segment elevation acute coronary syndrome: primary results of the DISPERSE- 2 trial. J. Am. Coll. Cardiol. 2007; 50(19):1844-1851. Investigators, D. [PubMed: 17980250]

[213]. Oestreich JH. Elinogrel, a reversible P2Y12 receptor antagonist for the treatment of acute coronary syndrome and prevention of secondary thrombotic events. Curr. Opin. Investig. Drugs. 2010; 11(3):340-348. 
[214]. Scarborough RM, Laibelman AM, Clizbe LA, Fretto LJ, Conley PB, Reynolds EE, Sedlock DM, Jantzen H. Novel tricyclic benzothiazolo[2,3-c]thiadiazine antagonists of the platelet ADP receptor(P2Y 12). Bioorg. Med. Chem. Lett. 2001; 11(14):1805-1808. [PubMed: 11459636]

[215]. Wang YX, Vincelette J, da Cunha V, Martin-McNulty B, Mallari C, Fitch RM, Alexander S, Islam I, Buckman BO, Yuan S, Post JM, Subramanyam B, Vergona R, Sullivan ME, Dole WP, Morser J, Bryant J. A novel P2 $\mathrm{Y}_{12}$ adenosine diphosphate receptor antagonist that inhibits platelet aggregation and thrombus formation in rat and dog models. Thromb. Haemost. 2007; 97(5):847-855. [PubMed: 17479197]

[216]. Andó RD, Méhész B, Gyires K, Illes P, Sperlágh B. A comparative analysis of the activity of ligands acting at $\mathrm{P} 2 \mathrm{X}$ and $\mathrm{P} 2 \mathrm{Y}$ receptor subtypes in models of neuropathic, acute and inflammatory pain. Br. J. Pharmacol. 2010; 159(5):1106-1117. [PubMed: 20136836]

[217]. Hoffmann K, Baqi Y, Morena MS, Glänzel M, Müller CE, von Kügelgen I. Interaction of new, very potent non-nucleotide antagonists with Arg256 of the human platelet P2Y12 receptor. J. Pharmacol. Exp. Ther. 2009; 331(2):648-655. [PubMed: 19690189]

[218]. Kunapuli SP, Ding Z, Dorsam RT, Kim S, Murugappan S, Quinton TM. ADP receptors--targets for developing antithrombotic agents. Curr. Pharm. Des. 2003; 9(28):2303-2316. [PubMed: 14529392]

[219]. Carrasquero LM, Delicado EG, Jiménez AI, Pérez-Sen R, Miras-Portugal MT. Cerebellar astrocytes co-express several ADP receptors. Presence of functional P2 $\mathrm{Y}_{13}$-like receptors. Purinergic Signal. 2005; 1(2):153-159. [PubMed: 18404500]

[220]. Sasaki Y, Hoshi M, Akazawa C, Nakamura Y, Tsuzuki H, Inoue K, Kohsaka S. Selective expression of Gi/o-coupled ATP receptor P2Y 12 in microglia in rat brain. Glia. 2003; 44(3):242250. [PubMed: 14603465]

[221]. Amadio S, Tramini G, Martorana A, Viscomi MT, Sancesario G, Bernardi G, Volonté C. Oligodendrocytes express P2Y12 metabotropic receptor in adult rat brain. Neuroscience. 2006; 141(3):1171-1180. [PubMed: 16831517]

[222]. Haynes SE, Hollopeter G, Yang G, Kurpius D, Dailey ME, Gan WB, Julius D. The P2Y12 receptor regulates microglial activation by extracellular nucleotides. Nat. Neurosci. 2006; 9(12): 1512-1519. [PubMed: 17115040]

[223]. Braganhol E, Morrone FB, Bernardi A, Huppes D, Meurer L, Edelweiss MI, Lenz G, Wink MR, Robson SC, Battastini AM. Selective NTPDase2 expression modulates in vivo rat glioma growth. Cancer Sci. 2009; 100(8):1434-1442. [PubMed: 19558578]

[224]. Zhang FL, Luo L, Gustafson E, Palmer K, Qiao X, Fan X, Yang S, Laz TM, Bayne M, Monsma FJ Jr. P2 $Y_{13}$ : identification and characterization of a novel Galphai-coupled ADP receptor from human and mouse. J. Pharmacol. Exp. Therap. 2002; 301(2):705-713. [PubMed: 11961076]

[225]. Burnstock G. Historical review: ATP as a neurotransmitter. Trends Pharmacol. Sci. 2006; 27(3): 166-176. [PubMed: 16487603]

[226]. Carrasquero LM, Delicado EG, Bustillo D, Gutiérrez-Martín Y, Artalejo AR, Miras-Portugal MT. P2X7 and P2Y13 purinergic receptors mediate intracellular calcium responses to BzATP in rat cerebellar astrocytes. J. Neurochem. 2009; 110(3):879-889. [PubMed: 19457067]

[227]. Marteau F, Le Poul E, Communi D, Labouret C, Savi P, Boeynaems JM, Gonzalez NS. Pharmacological characterization of the human P2Y13 receptor. Mol. Pharmacol. 2003; 64(1): 104-112. [PubMed: 12815166]

[228]. Malaval C, Laffargue M, Barbaras R, Rolland C, Peres C, Champagne E, Perret B, Terce F, Collet X, Martinez LO. RhoA/ROCK I signalling downstream of the P2Y13 ADP-receptor controls HDL endocytosis in human hepatocytes. Cell Signal. 2009; 21(1):120-127. [PubMed: 18948190]

[229]. Wang N, Robaye B, Agrawal A, Skerry TM, Boeynaems JM, Gartland A. Reduced bone turnover in mice lacking the $\mathrm{P}_{2} \mathrm{Y}_{13}$ receptor of ADP. Mol. Endocrinol. 2012; 26(1):142-152. [PubMed: 22108801]

[230]. Kim YC, Lee JS, Sak K, Marteau F, Mamedova L, Boeynaems JM, Jacobson KA. Synthesis of pyridoxal phosphate derivatives with antagonist activity at the P2Y13 receptor. Biochem. Pharmacol. 2005; 70(2):266-274. [PubMed: 15913566] 
[231]. Jiménez E, Zafra F, Pérez-Sen R, Delicado EG, Miras-Portugal MT, Aragón C, López-Corcuera B. P2Y purinergic regulation of the glycine neurotransmitter transporters. J. Biol. Chem. 2011; 286(12):10712-10724. [PubMed: 21245148]

[232]. Ortega F, Pérez-Sen R, Miras-Portugal MT. Gi-coupled P2Y-ADP receptor mediates GSK-3 phosphorylation and beta-catenin nuclear translocation in granule neurons. J. Neurochem. 2008; 104(1):62-73. [PubMed: 17986231]

[233]. Chambers JK, Macdonald LE, Sarau HM, Ames RS, Freeman K, Foley JJ, Zhu Y, McLaughlin MM, Murdock P, McMillan L, Trill J, Swift A, Aiyar N, Taylor P, Vawter L, Naheed S, Szekeres P, Hervieu G, Scott C, Watson JM, Murphy AJ, Duzic E, Klein C, Bergsma DJ, Wilson S, Livi GP. A G protein-coupled receptor for UDP-glucose. J. Biol. Chem. 2000; 275(15):10767-10771. [PubMed: 10753868]

[234]. Abbracchio MP, Boeynaems JM, Barnard EA, Boyer JL, Kennedy C, Miras-Portugal MT, King BF, Gachet C, Jacobson KA, Weisman GA, Burnstock G. Characterization of the UDP-glucose receptor(re-named here the $\mathrm{P} 2 \mathrm{Y} 14$ receptor) adds diversity to the $\mathrm{P} 2 \mathrm{Y}$ receptor family. Trends Pharmacol. Sci. 2003; 24(2):52-55. [PubMed: 12559763]

[235]. Gao ZG, Ding Y, Jacobson KA. UDP-glucose acting at P2Y14 receptors is a mediator of mast cell degranulation. Biochem. Pharmacol. 2010; 79(6):873-879. [PubMed: 19896471]

[236]. Ko H, Fricks I, Ivanov AA, Harden TK, Jacobson KA. Structure-activity relationship of uridine 5'-diphosphoglucose analogues as agonists of the human P2Y14 receptor. J. Med. Chem. 2007; 50(9):2030-2039. [PubMed: 17407275]

[237]. Moore DJ, Murdock PR, Watson JM, Faull RL, Waldvogel HJ, Szekeres PG, Wilson S, Freeman KB, Emson PC. GPR105, a novel Gi/o-coupled UDP-glucose receptor expressed on brain glia and peripheral immune cells, is regulated by immunologic challenge: possible role in neuroimmune function. Brain Res. Mol. Brain Res. 2003; 118(1-2):10-23. [PubMed: 14559350]

[238]. Skelton L, Cooper M, Murphy M, Platt A. Human immature monocyte-derived dendritic cells express the G protein-coupled receptor GPR105(KIAA0001, P2Y14) and increase intracellular calcium in response to its agonist, uridine diphosphoglucose. J. Immunol. 2003; 171(4):19411949. [PubMed: 12902497]

[239]. Arase T, Uchida H, Kajitani T, Ono M, Tamaki K, Oda H, Nishikawa S, Kagami M, Nagashima T, Masuda H, Asada H, Yoshimura Y, Maruyama T. The UDP-glucose receptor P2RY14 triggers innate mucosal immunity in the female reproductive tract by inducing IL-8. J. Immunol. 2009; 182(11):7074-7084. [PubMed: 19454705]

[240]. Bassil AK, Bourdu S, Townson KA, Wheeldon A, Jarvie EM, Zebda N, Abuin A, Grau E, Livi GP, Punter L, Latcham J, Grimes AM, Hurp DP, Downham KM, Sanger GJ, Winchester WJ, Morrison AD, Moore GB. UDP-glucose modulates gastric function through P2Y14 receptordependent and -independent mechanisms. Am. J. Physiol. Gastrointest. Liver Physiol. 2009; 296(4):G923-G930. [PubMed: 19164486]

[241]. Abbott NJ, Patabendige AA, Dolman DE, Yusof SR, Begley DJ. Structure and function of the blood-brain barrier. Neurobiol. Dis. 2010; 37(1):13-25. [PubMed: 19664713]

[242]. Mills JH, Thompson LF, Mueller C, Waickman AT, Jalkanen S, Niemela J, Airas L, Bynoe MS. CD73 is required for efficient entry of lymphocytes into the central nervous system during experimental autoimmune encephalomyelitis. Proc. Natl. Acad. Sci. USA. 2008; 105(27):93259330. [PubMed: 18591671]

[243]. Carman AJ, Mills JH, Krenz A, Kim DG, Bynoe MS. Adenosine receptor signaling modulates permeability of the blood-brain barrier. J. Neurosci. 2011; 31(37):13272-13280. [PubMed: 21917810]

[244]. Kukulski F, Ben Yebdri F, Bahrami F, Fausther M, Tremblay A, Sevigny J. Endothelial P2Y 2 receptor regulates LPS-induced neutrophil transendothelial migration in vitro. Mol. Immunol. 2010; 47(5):991-999. [PubMed: 20022380]

[245]. Seye CI, Yu N, Jain R, Kong Q, Minor T, Newton J, Erb L, Gonzalez FA, Weisman GA. The $\mathrm{P}_{2} \mathrm{Y}_{2}$ nucleotide receptor mediates UTP-induced vascular cell adhesion molecule-1 expression in coronary artery endothelial cells. J. Biol. Chem. 2003; 278(27):24960-24965. [PubMed: 12714597]

[246]. Ecke D, Hanck T, Tulapurkar ME, Schäfer R, Kassack M, Stricker R, Reiser G. Heterooligomerization of the $\mathrm{P}_{2} \mathrm{Y}_{11}$ receptor with the $\mathrm{P}_{2} \mathrm{Y}_{1}$ receptor controls the internalization and 
ligand selectivity of the $\mathrm{P}_{2} \mathrm{Y}_{11}$ receptor. Biochem. J. 2008; 409(1):107-116. [PubMed: 17824841]

[247]. Yoshioka K, Saitoh O, Nakata H. Heteromeric association creates a P2Y-like adenosine receptor. Proc. Natl. Acad. Sci. USA. 2001; 98(13):7617-7622. [PubMed: 11390975]

[248]. Tonazzini I, Trincavelli ML, Storm-Mathisen J, Martini C, Bergersen LH. Co-localization and functional cross-talk between $\mathrm{A} 1$ and $\mathrm{P} 2 \mathrm{Y}_{1}$ purine receptors in rat hippocampus. Eur. J. Neurosci. 2007; 26(4):890-902. [PubMed: 17672857]

[249]. Yoshioka K, Hosoda R, Kuroda Y, Nakata H. Hetero-oligomerization of adenosine A1 receptors with $\mathrm{P}_{2} \mathrm{Y}_{1}$ receptors in rat brains. FEBS Lett. 2002; 531(2):299-303. [PubMed: 12417330]

[250]. Tonazzini I, Trincavelli ML, Montali M, Martini C. Regulation of A1 adenosine receptor functioning induced by $\mathrm{P}_{2} \mathrm{Y}_{1}$ purinergic receptor activation in human astroglial cells. J. Neurosci. Res. 2008; 86(13):2857-2866. [PubMed: 18500760]

[251]. D'Alimonte I, Ciccarelli R, Di Iorio P, Nargi E, Buccella S, Giuliani P, Rathbone MP, Jiang S, Caciagli F, Ballerini P. Activation of $\mathrm{P} 2 \mathrm{X}_{7}$ receptors stimulates the expression of $\mathrm{P} 2 \mathrm{Y}_{2}$ receptor mRNA in astrocytes cultured from rat brain. Int. J. Immunopathol. Pharmacol. 2007; 20(2):301316. [PubMed: 17624242]

[252]. Bianco F, Pravettoni E, Colombo A, Schenk U, Möller T, Matteoli M, Verderio C. Astrocytederived ATP induces vesicle shedding and IL-1 beta release from microglia. J. Immunol. 2005; 174(11):7268-7277. [PubMed: 15905573]

[253]. Bours MJ, Dagnelie PC, Giuliani AL, Wesselius A, Di Virgilio F. P2 receptors and extracellular ATP: a novel homeostatic pathway in inflammation. Front. Biosci. (Schol. Ed.). 2011; 3:14431456. [PubMed: 21622280]

[254]. Arthur DB, Akassoglou K, Insel PA. P2Y2 receptor activates nerve growth factor/TrkA signaling to enhance neuronal differentiation. Proc. Natl. Acad. Sci. USA. 2005; 102(52):1913819143. [PubMed: 16365320]

[255]. Parvathenani LK, Tertyshnikova S, Greco CR, Roberts SB, Robertson B, Posmantur R. P2X7 mediates superoxide production in primary microglia and is up-regulated in a transgenic mouse model of Alzheimer's disease. J. Biol. Chem. 2003; 278(15):13309-13317. [PubMed: 12551918] 
Table 1

P2Y Receptor Agonists and Antagonists

\begin{tabular}{|c|c|c|c|}
\hline Receptor & Agonists & Antagonists & Potential Therapeutic Pathways \\
\hline $\mathrm{P} 2 \mathrm{Y}_{1}$ & $\begin{array}{l}\text { Endogenous: ADP } \\
\text { Synthetic: } 2 \text {-MeS-ADP, MRS 2365, } \\
\text { ATP-a-B derivatives, }(\text { Ap5 }(\gamma \text {-B)A), } \\
\beta, \gamma \text {-Me-ATP, Di-(2-MeS)-adenosine 5',5"- } \\
\mathrm{P}^{1}, \mathrm{P}^{4}, \mathrm{a}, \beta \text {-methylene-tetraphosphate, } \\
2 \text {-MeS- } \beta, \gamma-\mathrm{CCl}_{2} \text {-ATP }\end{array}$ & $\begin{array}{l}\text { PPADS, Suramin, } \\
\text { Reactive blue } 2 \text {, ATPaS, } \\
\beta, \gamma \text {-methylene-ATP, } \\
\text { A3P5PS, A3P5P, A2P5P, } \\
\text { MRS2179, } \\
\text { MRS2500, MRS2279 }\end{array}$ & $\begin{array}{l}\text { Antagonists can prevent } \\
\text { cytokine/chemokine-induced damage } \\
\text { following ischemia in mice, agonists can } \\
\text { induce axonal elongation in neurons and } \\
\text { modulation of pain sensation, antagonists } \\
\text { can reduce anxiolytic behavior in rats }\end{array}$ \\
\hline $\mathrm{P}_{2} \mathrm{Y}_{2}$ & $\begin{array}{l}\text { Endogenous: ATP or UTP } \\
\text { Synthetic: UTP } \gamma \text { S, Ap A, } \\
\text { INS365 (Diquafosol), INS37217 (Denusofol), } \\
\text { INS45973, 2'-amino-2'-deoxy-UTP, } \\
\text { 6-nitro-UTP, UTPaS, 2'-deoxy-UTPaS, } \\
\text { 2-thio-UTP, MRS2768, PSB1114 }\end{array}$ & $\begin{array}{l}\text { PPADS, Suramin, } \\
\text { Reactive blue 2, PSB716 }\end{array}$ & $\begin{array}{l}\text { Agonists can increase the migration of glial } \\
\text { cells through } P 2 Y^{2} \mathrm{R} / \text { integrin interactions, } \\
\text { proliferation of glial cells, non- } \\
\text { amyloidogenic APP processing in neurons, } \\
\text { and the uptake and degradation of } \\
\text { neurotoxic forms of } A \beta_{1-42} \text { by microglial cells }\end{array}$ \\
\hline $\mathrm{P}_{2} \mathrm{Y}_{4}$ & $\begin{array}{l}\text { Endogenous: UTP (humans), UTP or ATP } \\
\text { (mice, } \\
\text { rats) } \\
\text { Synthetic: UTP } \gamma \text { S, 5-bromo-UTP, } \\
\text { INS365 (Diquafosol), INS37217 (Denusofol), } \\
\text { 2'- } \\
\text { azido-2'-deoxy-UTP }\end{array}$ & PPADS, Reactive blue 2 & $\begin{array}{l}\mathrm{P} 2 \mathrm{Y}^{4} \mathrm{R} \text { activation can inhibit presynaptic } \\
\text { glutamate release, modulate blood-brain } \\
\text { barrier function, and inhibit } \mathrm{K}^{+} \text {currents in } \\
\text { rat myocytes }\end{array}$ \\
\hline $\mathrm{P}_{2} \mathrm{Y}_{6}$ & $\begin{array}{l}\text { Endogenous: UDP } \\
\text { Synthetic: UDPpS, MRS2693, PSB0474, } \\
\text { INS48823, a, } \beta \text {-methylene-UDP, 5-bromo-UTP }\end{array}$ & $\begin{array}{l}\text { PPADS, Suramin, } \\
\text { Reactive blue 2, MRS2567, } \\
\text { MRS2578, MRS2575 }\end{array}$ & $\begin{array}{l}\mathrm{P} 2 \mathrm{Y}_{6} \mathrm{R} \text { activation can increase phagocytic } \\
\text { activity of microglia and regulate repair } \\
\text { mechanisms in response to CNS injury }\end{array}$ \\
\hline $\mathrm{P} 2 \mathrm{Y}_{11}$ & $\begin{array}{l}\text { Endogenous: ATP } \\
\text { Synthetic: ATP } \gamma \text { S, BzATP, UTP, AR-C67085, } \\
\text { NF546, NAD+, NADP+ }\end{array}$ & $\begin{array}{l}\text { Suramin, Reactive blue } 2, \\
\text { AMPaS, } \\
\text { NF157, NF340 }\end{array}$ & $\begin{array}{l}\mathrm{P} 2 \mathrm{Y}_{11} \mathrm{R} \text { activation delays pathogen- or } \\
\text { inflammation-induced apoptosis in } \\
\text { neutrophils, inhibits TLR signaling and } \\
\text { modulates cytokine release }\end{array}$ \\
\hline $\mathrm{P} 2 \mathrm{Y}_{12}$ & $\begin{array}{l}\text { Endogenous: ADP } \\
\text { Synthetic: 2-MeS-ATP, 2-MeS-ADP }\end{array}$ & $\begin{array}{l}\text { Clopidogrel (Plavix), } \\
\text { Ticlopidine } \\
\text { (Ticlid), Prasugrel (Effient), } \\
\text { Ticagrelor (Brillinta), } \\
\text { Elinogrel, AR- } \\
\text { C67085, AR-C66096, } \\
\text { AR-C69931, CT50547, } \\
\text { BX-667, } \\
\text { MRS2395, PSB0739 }\end{array}$ & $\begin{array}{l}\mathrm{P} 2 \mathrm{Y}_{12} \mathrm{R} \text { antagonists are in widespread } \\
\text { clinical use as inhibitors of platelet } \\
\text { aggregation, and } \mathrm{P} 2 \mathrm{Y}_{12} \mathrm{R} \text { activation can } \\
\text { regulate glial cell migration and increase cell } \\
\text { proliferation }\end{array}$ \\
\hline $\mathrm{P} 2 \mathrm{Y}_{13}$ & $\begin{array}{l}\text { Endogenous: ADP } \\
\text { Synthetic: 2-MeS-ADP, } \\
\text { 2-MeS-ATP, ADP } \beta S, \text { BzATP }\end{array}$ & $\begin{array}{l}\text { PPADS, Suramin, } \\
\text { Reactive blue 2, Ap } 4 \text { A, } \\
\text { AR-C69931, AR-C67085, } \\
\text { MRS2211, } \\
\text { MRS2603 }\end{array}$ & $\begin{array}{l}\mathrm{P} 2 \mathrm{Y}_{13} \mathrm{R} \text { activation enhances glycine } \\
\text { transport in the synaptic cleft, and promotes } \\
\text { cell survival through a PI } 3 \mathrm{~K} / \text { Akt-dependent } \\
\text { mechanism }\end{array}$ \\
\hline $\mathrm{P} \mathrm{Y}_{14}$ & $\begin{array}{l}\text { Endogenous: UDP-glucose } \\
\text { Other: UDP-galactose, UDP-glucuronic acid, } \\
\text { UDP-N-acetylglucosamine } \\
\text { Synthetic: MRS } 2690\end{array}$ & & $\begin{array}{l}\mathrm{P} 2 \mathrm{Y}_{14} \mathrm{R} \text { activation can modulate } \\
\text { inflammatory responses through chemokine } \\
\text { and cytokine production, and may play a } \\
\text { role in muscle contraction }\end{array}$ \\
\hline
\end{tabular}

The EC50 values for endogenous agonists, the chemical names of agonists and antagonists and the associated references are given in the main text. 